\title{
Medical Marijuana Laws, Traffic Fatalities, and Alcohol Consumption
}

\author{
D. Mark Anderson \\ Department of Agricultural Economics and Economics \\ Montana State University \\ dwight.anderson@montana.edu \\ Benjamin Hansen \\ Department of Economics \\ University of Oregon \\ bchansen@uoregon.edu \\ Daniel I. Rees \\ Department of Economics \\ University of Colorado Denver \\ daniel.rees@ucdenver.edu
}

October 2012

To date, 17 states have passed medical marijuana laws, yet very little is known about their effects. The current study examines the relationship between the legalization of medical marijuana and traffic fatalities, the leading cause of death among Americans ages 5 through 34. The first full year after coming into effect, legalization is associated with an 8 to 11 percent decrease in traffic fatalities. The impact of legalization on traffic fatalities involving alcohol is larger and estimated with more precision than its impact on traffic fatalities that do not involve alcohol. Legalization is also associated with sharp decreases in the price of marijuana and alcohol consumption, a pattern of results consistent with the hypothesis that marijuana and alcohol are substitutes. Because alternative mechanisms cannot be ruled out, the negative relationship between legalization and alcohol-related traffic fatalities does not necessarily imply that driving under the influence of marijuana is safer than driving under the influence of alcohol. 


\section{INTRODUCTION}

Medical marijuana laws (hereafter MMLs) remove state-level penalties for using, possessing and cultivating medical marijuana. Patients are required to obtain approval or certification from a doctor, and doctors who recommend marijuana to their patients are immune from prosecution. MMLs allow patients to designate caregivers who can obtain marijuana on their behalf.

On June 1, 2012 Connecticut became the 17th state, along with the District of Columbia, to enact a MML. More than a dozen state legislatures, including those of Illinois, New York, and Pennsylvania have recently considered medical marijuana bills. If these bills are eventually signed into law, the majority of Americans will live in states that permit the use of medical marijuana.

Opponents of medical marijuana tend to focus on the social issues surrounding substance use. They argue that marijuana is addictive, serves as a gateway drug, has little medicinal value, and leads to criminal activity (Adams 2008; Blankstein 2010). Proponents argue that marijuana is both efficacious and safe, and can be used to treat the side effects of chemotherapy as well as the symptoms of AIDS, multiple sclerosis, epilepsy, glaucoma and other serious illnesses. They cite clinical research showing that marijuana relieves chronic pain, nausea, muscle spasms and appetite loss (Eddy 2010; Marmor 1998; Watson et al. 2000), and note that neither the link between medical marijuana and the use of other substances, nor the link between medical marijuana and criminal activity, has been substantiated (Belville 2011; Corry et al. 2009; Hoeffel 2011; Lamoureux 2011).

This study begins by exploring the effect of MMLs on the market for marijuana using price data collected from back issues of High Times, the leading cannabis-related magazine in 
the United States. Our results are consistent with anecdotal evidence that MMLs have led to a substantial increase in the supply of high-grade marijuana (Montgomery 2010). In contrast, the impact of MMLs on the market for low-quality marijuana appears to be modest.

Next, we turn our attention to MMLs and traffic fatalities, the primary relationship of interest. Traffic fatalities are the leading cause of death among Americans ages 5 through 34 (Centers for Disease Control and Prevention 2010). To our knowledge, there has been no previous examination of this relationship. Data on traffic fatalities at the state level are obtained from the Fatality Analysis Reporting System (FARS) for the years 1990-2010. Fourteen states and the District of Columbia enacted a MML during this period. FARS includes the time of day the traffic fatality occurred, the day of the week it occurred, and whether alcohol was involved. Using this information, we contribute to the long-standing debate on whether marijuana and alcohol are substitutes or complements.

The first full year after coming into effect, the legalization of medical marijuana is associated with an 8 to 11 percent decrease in traffic fatalities. However, the effect of MMLs on traffic fatalities involving alcohol is larger and estimated with more precision than the effect of MMLs on traffic fatalities that do not involve alcohol. In addition, we find that the estimated effects of MMLs on fatalities at night and on weekends (when alcohol consumption rises) are larger, and are more precise, than the estimated effects of MMLs on fatalities during the day and on weekdays.

Finally, the relationship between MMLs and more direct measures of alcohol consumption is examined. Using individual-level data from the Behavioral Risk Factor Surveillance System (BRFSS) for the period 1993-2010, we find that MMLs are associated with 
decreases in the probability of having consumed alcohol in the past month, binge drinking and the number of drinks consumed.

We conclude that alcohol is the likely mechanism through which the legalization of medical marijuana reduces traffic fatalities. However, this conclusion does not necessarily imply that driving under the influence of marijuana is safer than driving under the influence of alcohol. Alcohol is often consumed in restaurants and bars, while many states prohibit the use of medical marijuana in public. If marijuana consumption typically takes place at home or other private locations, then legalization could reduce traffic fatalities simply because marijuana users are less likely to drive while impaired.

\section{BACKGROUND}

\subsection{A brief history of medical marijuana}

Marijuana was introduced in the United States in the early-1600s by Jamestown settlers who used the plant in hemp production; hemp cultivation remained a prominent industry until the mid-1800s (Deitch 2003). During the census of 1850, the United States recorded over 8,000 cannabis plantations of at least 2,000 acres (U.K. Cannabis Campaign 2011). Throughout this period, marijuana was commonly used by physicians and pharmacists to treat a broad spectrum of ailments (Pacula et al. 2002). From 1850 to 1942, marijuana was included in the United States Pharmacopoeia, the official list of recognized medicinal drugs (Bilz 1992).

In 1913, California passed the first marijuana prohibition law aimed at recreational use (Gieringer 1999); by 1936, the remaining 47 states had followed suit (Eddy 2010). In 1937, the Marihuana Tax Act effectively discontinued the use of marijuana for medicinal purposes (Bilz 
1992), and marijuana was classified as a Schedule I drug in $1970 .{ }^{1}$ According to the Controlled Substances Act (CSA), a Schedule I drug must have a "high potential for abuse" and "no currently accepted medical use in treatment in the United States” (Eddy 2010).

In 1996, California passed the Compassionate Use Act, which removed criminal penalties for using, possessing and cultivating medical marijuana. It also provided immunity from prosecution to physicians who recommended the use of medical marijuana to their patients. Before 1996, a number of states allowed doctors to prescribe marijuana, but this had little practical effect because of federal restrictions. ${ }^{2}$ Since 1996, 16 other states and the District of Columbia have joined California in legalizing the use of medical marijuana (Table 1), although it is still classified as a Schedule I drug by the Federal government. ${ }^{3}$

\subsection{Studies on substance use and driving}

Laboratory studies have shown that cannabis use impairs driving-related functions such as distance perception, reaction time, and hand-eye coordination (Kelly et al. 2004; Sewell et al. 2009). However, neither simulator nor driving-course studies provide consistent evidence that these impairments to driving-related functions lead to an increased risk of collision (Kelly et al. 2004; Sewell et al. 2009) perhaps because drivers under the influence of tetrahydrocannabinol

\footnotetext{
${ }^{1}$ The Marihuana Tax Act imposed a registration tax and required extensive record-keeping, increasing the cost of prescribing marijuana as compared to other drugs (Bilz 1992).

${ }^{2}$ Federal regulations prohibit doctors from writing prescriptions for marijuana. In addition, even if a doctor were to illegally prescribe marijuana, it would be against federal law for pharmacies to distribute it. Doctors in states that have legalized medical marijuana avoid violating federal law by recommending marijuana to their patients rather than prescribing its use.

${ }^{3}$ Information on when MMLs were passed was obtained from a recent Congressional Research Services Report by Eddy (2010). Although the New Jersey medical marijuana law came into effect on October 1, 2010, implementation has been delayed (Brittain 2012). Coding New Jersey as a non-medical marijuana state in 2010 has no appreciable impact on the results presented below.
} 
(THC), the primary psychoactive substance in marijuana, engage in compensatory behaviors such as reducing their velocity, avoiding risky maneuvers, and increasing their "following distances" (Kelly et al. 2004; Sewell et al. 2009).

Like marijuana, alcohol impairs driving-related functions such as reaction time and handeye coordination (Kelly et al. 2004; Sewell et al. 2009). Moreover, simulator and driving-course studies provide unequivocal evidence that alcohol consumption leads to an increased risk of collision (Kelly et al. 2004; Sewell et al. 2009). Even at low doses, drivers under the influence of alcohol tend to underestimate the degree to which they are impaired (MacDonald et al. 2008; Marczinski et al. 2008; Robbe and O'Hanlon 1993; Sewell et al. 2009), drive at faster speeds, and take more risks (Burian et al. 2002; Ronen et al. 2008; Sewell et al. 2009). When used in conjunction with marijuana, alcohol appears to have an "additive or even multiplicative" effect on driving-related functions (Sewell et al. 2009, p. 186), although chronic marijuana users may be less impaired by alcohol than infrequent users (Jones and Stone 1970; Marks and MacAvoy 1989; Wright and Terry 2002). ${ }^{4}$

\subsection{The relationship between marijuana and alcohol}

Although THC has not been linked to an increased risk of collision in simulator and driving-course studies, MMLs could impact traffic fatalities through the consumption of alcohol. While a number of studies have found evidence of complementarity between marijuana and alcohol (Pacula 1998; Farrelly et al. 1999; Williams et al. 2004), others lend support to the hypothesis that marijuana and alcohol are substitutes. For instance, Chaloupka and Laixuthai

\footnotetext{
${ }^{4}$ A large body of research in epidemiology attempts to assess the effects of substance use based on observed THC and alcohol levels in the blood of drivers who have been in accidents. For marijuana, the results have been mixed, while the likelihood of an accident occurring clearly increases with BAC levels (Sewell et al. 2009).
} 
(1997) and Saffer and Chaloupka (1999) found that marijuana decriminalization led to decreased alcohol consumption, while DiNardo and Lemieux (2001) found that increases in the minimum legal drinking age were positively associated with the use of marijuana.

Two recent studies used a regression discontinuity approach to examine the effect of the minimum legal drinking age on marijuana use, but came to different conclusions. Crost and Guerrero (2012) analyzed data from the National Survey on Drug Use and Health (NSDUH). They found that marijuana use decreased sharply at 21 years of age, evidence consistent with substitutability between alcohol and marijuana. In contrast, Yörük and Yörük (2011), who drew on data from the National Longitudinal Survey of Youth 1997 (NLSY97), concluded that alcohol and marijuana were complements. However, these authors appear to have inadvertently conditioned on having used marijuana at least once since the last interview. When Crost and Rees (forthcoming) applied Yörük and Yörük’s (2011) research design to the NLSY97 data without conditioning on having used marijuana since the last interview, they found no evidence that alcohol and marijuana were complements.

\section{MEDICAL MARIJUNA LAWS AND THE MARIJUANA MARKET}

MMLs should, in theory, increase both the supply of marijuana and the demand for marijuana, unambiguously leading to an increase in consumption (Pacula et al. 2010). They afford suppliers some protection against prosecution, and allow patients to buy medical marijuana without fear of being arrested or fined, lowering the full cost of obtaining marijuana. ${ }^{5}$

\footnotetext{
${ }^{5}$ The majority of MMLs allow patients to register based on medical conditions that cannot be objectively confirmed (e.g. chronic pain and nausea). In fact, chronic pain is the most common medical condition among patients seeking treatment (Appendix Table 1). According to recent Arizona registry data, only 7 out of 11,186 applications for medical marijuana have been denied approval. Sun (2010) described "quick-in, quick-out mills," where physicians provide recommendations for a nominal fee. Cochran (2010) reported on doctors who provide medical marijuana recommendations to patients via brief web interviews on Skype.
} 
Because it is prohibitively expensive for the government to ensure that all medicinal marijuana ends up in the hands of registered patients (especially in states that permit home cultivation), diversion to non-patients almost certainly occurs. ${ }^{6}$

The NSDUH is the best source of information on marijuana consumption by adults living in the United States. However, the NSDUH does not provide individual-level data with state identifiers to researchers, and did not publish state-level estimates of marijuana use prior to 1999. ${ }^{7}$ Because 5 states (including California, Oregon and Washington) legalized medical marijuana during the period 1996 -1999, we turn to back issues of High Times magazine in order to gauge the impact of legalization on the marijuana market. Begun in 1975, High Times is published monthly and covers topics ranging from marijuana cultivation to politics. Each issue also contains a section entitled "Trans High Market Quotations" in which readers provide marijuana prices from across the country. In addition to price, a typical entry includes information about where the marijuana was purchased, its strain and its quality.

We collected price information from High Times for the period 1990 through 2011. Jacobson (2004), who collected information on the price of marijuana from High Times for the

\footnotetext{
${ }^{6}$ Aside from Washington D.C. and New Jersey, all MMLs enacted during the period 1990-2010 allowed for home cultivation, and 8 out of 15 allowed patients or caregivers to cultivate collectively (Appendix Table 2). A recent investigation concluded that thousands of pounds of medical marijuana grown in Colorado are diverted annually to the recreational market (Wirfs-Brock et al. 2010). See also Thurstone et al. (2011) who interviewed 80 adolescents (15 through 19 years of age) undergoing outpatient substance abuse treatment in Denver. Thirty-nine of the 80 reported having obtained marijuana from someone with a medical marijuana license. Florio (2011) described the story of 4 8th-graders in Montana who received marijuana-laced cookies from a registered medical marijuana patient.

${ }^{7}$ Using these estimates, Wall et al. (2011) found that rates of marijuana use among 12-through 17-year-olds were higher in states that had legalized medical marijuana than in states that had not, but noted that "in the years prior to MML passage, there was already a higher prevalence of use and lower perceptions of risk" in states that had legalized medical marijuana. Using NSDUH data for the years 2002 through 2009, Harper et al. (2012) found that legalization was associated with a small reduction in the rate of marijuana use among 12- through 17-year-olds. Using data for the period 1995-2002 from Denver, Los Angeles, Portland, San Diego and San Jose, Gorman and Huber Jr. (2007) found little evidence that marijuana consumption increased among adult arrestees as a result of legalization.
} 
period 1975 through 2000, distinguished between high-quality (a category that included

Californian and Hawaiian "sensimilla") and low-quality marijuana (a category that included commercial grade Colombian and Mexican "weed"). ${ }^{8}$ Following Jacobson (2004), we classified marijuana purchases by quality, and calculated the median per-ounce price by state and year. ${ }^{9}$ Table 2A presents estimates of the following equation:

$$
\ln \left(\text { Price High-Quality Marijuana }{ }_{s t}\right)=\beta_{0}+\beta_{1} M M L_{s t}+\boldsymbol{X}_{s t} \boldsymbol{\beta}_{2}+v_{s}+w_{t}+\varepsilon_{s t},
$$

where $s$ indexes states and $t$ indexes years. The variable $M M L_{s t}$ indicates whether medical marijuana was legal in state $s$ and year $t$, and $\beta_{l}$ represents the estimated relationship between legalization and the per-ounce price of high-quality marijuana. The vector $\boldsymbol{X}_{s t}$ includes controls for the mean age in state $s$ and year $t$, the unemployment rate, per capita income, whether the state had a marijuana decriminalization law in place, and the beer tax. State fixed effects,

\footnotetext{
${ }^{8}$ Plant variety (i.e., strain), which part of the plan is used, method of storage, and cultivation techniques are all important determinants of quality/potency (McLaren et al. 2008). In recent decades there has been a marked trend towards indoor cultivation and higher potency in the United States (McLaren et al. 2008). Jacobson (2004) argued that, ideally, prices would be deflated by a measure of potency. Unfortunately, information on potency is not available in the High Times data.

${ }^{9}$ A total of 8,271 purchases were coded. Of these, 7,029 were classified as high-quality and 1,242 were classified as low-quality. Prior to 2004, information on the seller was occasionally included in the Trans High Market Quotations section of High Times. Although dispensaries were never mentioned, they are a relatively recent phenomenon. The number of dispensaries in California expanded rapidly after 2004 (Jacobson 2011), and the number of dispensaries in Colorado and Montana expanded rapidly after 2008 (Smith 2011; Smith 2012). We compared High Times price data from 2011-2012 with price data posted on the internet by 84 dispensaries located in 7 states. In 4 out of the 7 states (California, Michigan, Nevada and Washington) prices charged by dispensaries were statistically indistinguishable from the prices provided by High Times readers. In Arizona, Colorado and Oregon, prices charged by dispensaries were significantly lower than prices provided by High Times readers; however, these differences were generally not large in magnitude. The greatest difference was in Colorado, where dispensaries, on average, charged 24.4 percent less per ounce (\$72.8) than the prices provided by High Times readers. In Arizona, dispensaries, on average, charged 10.3 percent less per ounce (\$36.6) than the prices provided by High Times readers; in Oregon, dispensaries, on average, charged 14.9 percent less per ounce $(\$ 37.2)$ than the prices provided by High Times readers. Dispensary price data are available at: www.legalmarijuanadispensary.com.
} 
represented by $v_{s}$, control for time-invariant unobservables at the state level; year fixed effects, represented by $w_{t}$, control for common shocks to the price of high-quality marijuana. ${ }^{10}$

The baseline estimate, in column (1) of Table 2A, suggests that the supply response to legalization is larger than the demand response. Specifically, legalization is associated with a 26.2 percent $\left(\mathrm{e}^{-0.304}-1=-0.262\right)$ decrease in the price of high-quality marijuana. When we include state-specific linear time trends, intended to control for omitted variables at the state level that evolve at a constant rate, legalization is associated with a 9.8 percent decrease in the price of high-quality marijuana.

Lagging the MML indicator provides evidence that the effect of legalization on the price of high-quality marijuana is not immediate. Controlling for state-specific linear time trends, the estimated coefficients of the MML indicator lagged 1-3 years are negative, but not statistically significant. There is a statistically significant 24.6 percent reduction in the price of high-quality marijuana the fourth full year after legalization. This pattern of results is consistent with state registry data from Colorado, Montana, and Rhode Island showing that patient numbers increased slowly in the years immediately after legalization. ${ }^{11}$ Adding leads to the model with state-

\footnotetext{
${ }^{10}$ Standard errors are corrected for clustering at the state level (Bertrand et al. 2004). Descriptive statistics are presented in Appendix Table 3. Mean age in state $s$ and year $t$ was calculated using Census data. Data on beer taxes are from the Brewers Almanac, an annual publication produced by the Beer Institute. The unemployment and income data are from the Bureau of Labor Statistics and the Bureau of Economic Analysis, respectively. Data on decriminalization laws are from Model (1993) and Scott (2010). During the period under study, the decriminalization indicator only captures two policy changes: Nevada and Massachusetts decriminalized the use of marijuana in 2001 and 2010, respectively. The majority of decriminalization laws were passed prior to 1990. Following Jacobson (2004), the estimates presented in Tables 2A and 2B are unweighted. When the regressions are weighted by the number of observations used to calculate median price and state-specific linear time trends are included on the right-hand side, estimates of the relationship between legalization and price are smaller and less precise. Nevertheless, they continue to show that legalization is associated with a statistically significant reduction in the price of high-quality marijuana after 4 years. When the regressions are weighted by the number of observations used to calculate median price but state-specific linear time trends are not included on the right-hand side, estimates of relationship between legalization and price are almost identical to those reported in Tables $2 \mathrm{~A}$ and $2 \mathrm{~B}$.
}

${ }^{11}$ Appendix Table 1 presents registry information by state. Montana legalized medical marijuana in November 2004. Two years later, only 287 patients were registered; seven years later, 30,036 patients were registered. The 
specific linear time trends produces no evidence that legalization was systematically preceded by changes in tastes or policies related to the market for high-quality marijuana.

Estimates of the relationship between legalization and the price of low-quality marijuana are presented in Table $2 \mathrm{~B}$. The majority of these estimates are negative. However, with two exceptions, they are statistically insignificant. Given that much of the medicinal crop is grown indoors under ultraviolet lights, and that high-potency and high-quality strains such as "Northern Lights" and "Super Silver Haze" are favored by medical marijuana cultivators, this imprecision is not surprising.

\section{MEDICAL MARIJUNA LAWS AND TRAFFIC FATALITIES}

The estimates discussed above suggest that legalization leads to a substantial decrease in the price of high-quality marijuana and, presumably, a correspondingly-large increase in consumption. ${ }^{12}$ In this section, we test whether the impact of legalization extends to traffic fatalities.

\subsection{Data on traffic fatalities}

As noted above, we use data from the Fatal Accident Report System (FARS) for the period 1990-2010 to examine the relationship between MMLs and traffic fatalities. These data

\footnotetext{
number of registered patients in Colorado increased from 5,051 in January 2009 to 128,698 in June 2011. Patient numbers also appear to be growing rapidly in Arizona, which passed the Arizona Medical Marijuana Act on November 2, 2010. Eleven thousand one hundred and thirty-three patient applications had been approved as of August 29, 2011; 40,463 patient applications had been approved by June 30, 2012.

${ }^{12}$ If we assume, conservatively, that legalization has a negligible impact on demand, then the change in marijuana consumption is equal to the elasticity of demand multiplied by the percent change in price. Only a handful of papers have estimated the price elasticity of demand for marijuana. Using data on UCLA undergraduates, Nisbet and Vakil (1972) estimated a price elasticity of demand between -1.01 and -1.51; using data from Monitoring the Future on high school seniors, Pacula et al. (2001) estimated a 30-day participation elasticity between -0.002 and -0.69 ; using data from the Harvard College Alcohol Study, Williams et al. (2004) estimated a 30-day participation elasticity of -0.24 .
} 
are collected by the National Highway Traffic Safety Administration, and represent an annual census of all fatal injuries suffered in motor vehicle accidents in the United States. Information on the circumstances of each crash and the persons and vehicles involved is obtained from a variety of sources, including police crash reports, driver licensing files, vehicle registration files, state highway department data, emergency medical services records, medical examiner reports, toxicology reports, and death certificates.

Table 3 presents descriptive statistics and definitions for our outcome measures.

Fatalities Total $_{s t}$ is equal to the number of traffic fatalities per 100,000 population of state $s$ in year $t .{ }^{13}$ The variables Fatalities $(B A C>0)_{s t}$ and Fatalities $(B A C \geq 0.10)_{s t}$ allow us to examine the effects of legalization by alcohol involvement. Fatalities $(B A C>0)_{s t}$ is equal to the number of traffic fatalities per 100,000 population resulting from accidents in which at least one driver had a positive blood alcohol concentration. Fatalities $(B A C \geq 0.10)_{s t}$ is defined analogously, but at least one driver had to have a blood alcohol concentration greater than or equal to 0.10 .

Fatalities (No Alcohol) st is equal to the number of fatalities per 100,000 population in which alcohol involvement was not reported. ${ }^{14}$ Alcohol involvement is likely measured with error (Eisenberg 2003), and the possibility exists that some states collected information on BAC levels more diligently than others. ${ }^{15}$ Focusing on nighttime and weekend fatal crashes can provide

\footnotetext{
${ }^{13}$ Population data come from the National Cancer Institute and are available at: http://seer.cancer.gov/popdata/index.html. According to Eisenberg (2003), traffic fatalities in FARS are measured with little to no error. We experimented with scaling traffic fatalities by the population of licensed drivers and by the number of miles driven in state $s$ and year $t$ rather than by the state population. These estimates, which are similar in terms of magnitude and precision to those presented below, are available upon request.

${ }^{14}$ The numerator for Fatalities (No Alcohol) st $_{\text {was }}$ was determined from two sources in the FARS. First, all drivers involved had to have either registered a $\mathrm{BAC}=0$ or, if $\mathrm{BAC}$ information was missing, the police had to report that alcohol was not involved.

${ }^{15} \mathrm{We}$ also experimented with calculating the alcohol-related fatality rates based on the imputed BAC levels available in the FARS data. These estimates, which are similar in terms of magnitude and precision to those
} 
additional insight into the role of alcohol and help address the measurement error issue. As noted by Dee (1999), a substantial proportion of fatal crashes on weekends and at night involve alcohol.

According to state registry data, 75 percent of patients in Arizona, and 69 percent of patients in Colorado, are male. There is also evidence that many medical marijuana patients are below the age of 40. Forty-eight percent of registered patients in Montana, and 42 percent of registered patients in Arizona, are between the ages of 18 and 40; the average age of registered patients in Colorado is $40 .{ }^{16}$ To the extent that registered patients below the age of 40 are more likely to use medical marijuana recreationally, heterogeneous effects across the age distribution might be expected.

Figures 1-3 compare pre- and post-legalization traffic fatality trends by age group. The solid line represents the average traffic fatality rate for the treated states (those that legalized medical marijuana). The dashed line represents the average fatality rate for the control states (those that did not legalize medical marijuana). Year 0 on the horizontal axis represents the year in which legalization took place. Control states were randomly assigned a year of legalization between 1996 and 2010.

Among teenagers (ages 15 through 19), young adults (ages 20 through 39) and older adults (ages 40 and above), average traffic fatality rates in the treated states closely follow those in the control states through year -1. This finding is important because it suggests that legalization was not preceded by, for instance, new anti-drunk driving policies, increased spending on law enforcement, or highway improvements. In the years immediately after

presented below, are available upon request. See Adams et al. (2012) for a discussion of the BAC imputation method.

${ }^{16}$ Links to state registry data are available at: http://norml.org/index.cfm?Group ID=3391. 
legalization, average traffic fatality rates in MML states fall faster than average traffic fatality rates in the control states. This divergence is most pronounced among 20 through 39 year olds. Among teenagers and older adults, average traffic fatality rates in MML states converge with average traffic fatality rates in the control states 4 to 5 years after legalization.

\subsection{The empirical model}

To further explore the relationship between legalization and traffic fatalities, we estimate the following baseline equation:

$$
\ln \left(\text { Fatalities } \text { Total }_{s t}\right)=\beta_{0}+\beta_{1} M M L_{s t}+\boldsymbol{X}_{s} \boldsymbol{\beta}_{2}+v_{s}+w_{t}+\varepsilon_{s t},
$$

where $s$ indexes states and $t$ indexes years. The coefficient of interest, $\beta_{1}$, represents the effect of legalizing medical marijuana. ${ }^{17}$ In alternative specifications we replace Fatalities Total $_{s t}$ with the remaining outcomes listed in Table 3 .

The vector $\boldsymbol{X}_{s t}$ is composed of the controls described in Table 4, and $v_{s}$ and $w_{t}$ are state and year fixed effects, respectively. Previous studies provide evidence that a variety of statelevel policies can impact traffic fatalities. For instance, graduated driver licensing regulations and stricter seatbelt laws are associated with fewer traffic fatalities (Cohen and Einav 2003; Dee et al. 2005; Freeman 2007; Carpenter and Stehr 2008). Other studies have examined the effects of speed limits (Ledolter and Chan 1996; Farmer et al. 1999; Greenstone 2002; Dee and Sela 2003), administrative license revocation laws (Freeman 2007), BAC laws (Dee 2001; Eisenberg 2003; Young and Bielinska-Kwapisz 2006; Freeman 2007), Zero Tolerance Laws (Carpenter

\footnotetext{
${ }^{17}$ This specification is based on Dee (2001), who examined the relationship between BAC 0.08 laws and traffic fatalities.
} 
2004; Liang and Huang 2008; Grant 2010), and cellphone bans (Kolko 2009). The relationship between beer taxes and traffic fatalities has also received attention from economists (Chaloupka et al. 1991; Ruhm 1996; Dee 1999; Young and Likens 2000; Young and Bielinska-Kwapisz 2006). ${ }^{18}$ In addition to these polices, we include mean age in state $s$ and year $t$, the unemployment rate, real per capita income, vehicle miles driven per licensed driver, and indicators for marijuana decriminalization and whether a drug per se law was in place. ${ }^{19}$

\subsection{The relationship between MMLs and traffic fatalities}

Table 5 presents OLS estimates of the relationship between MMLs and traffic fatalities. The regressions are weighted by the population of state $s$ in year $t$, and the standard errors are corrected for clustering at the state level (Bertrand et al. 2004). The baseline estimate, in column (1), suggests that legalization leads to a 10.4 percent decrease in the fatality rate. ${ }^{20}$ When we include state-specific linear time trends, the estimate of $\beta_{1}$ retains its magnitude but is no longer statistically significant at conventional levels $(\mathrm{p}$-value $=0.139)$.

\footnotetext{
${ }^{18}$ Information on graduated driver licensing laws and seatbelt requirements is available from Dee et al. (2005), Cohen and Einav (2003), and the Insurance Institute for Highway Safety (iihs.org). Information on administrative license revocation laws and BAC limits is available from Freeman (2007). The FARS accident files were used to construct the variable Speed 70. Data on beer taxes are from the Brewers Almanac, an annual publication produced by the Beer Institute. Data on whether texting while driving was banned and whether using a handheld cellphone while driving was banned are from www.handsfreeinfo.com.

${ }^{19}$ Mean age in state $s$ and year $t$ was calculated using U.S. Census data. Information on vehicle miles driven per licensed driver is from Highway Statistics, an annual publication produced by the U.S. Department of Transportation. We recognize that legalization of medical marijuana could have a direct impact on miles driven, but follow previous research on traffic fatalities by including it as a control variable (Dills 2010; Eisenberg 2003; Young and Likens 2000). The unemployment and income data are from the Bureau of Labor Statistics and the Bureau of Economic Analysis, respectively. Data on decriminalization laws are from Model (1993) and Scott (2010). Data on drug per se laws, which prohibit the operation of a motor vehicle with drugs (or drug metabolites) in the system, are from the National Highway Traffic Safety Administration (2010).

${ }^{20}$ Controlling for economic conditions and policies (such as whether a primary seatbelt law was in effect or whether a state had a $0.08 \mathrm{BAC}$ law) has only a small impact on our estimate of $\beta_{1}$. In fact, when the covariates listed in Table 5 are excluded from the regression, the estimated coefficient reported in the first column of Table 5 changes from -0.110 to -0.118 .
} 
In columns (3) through (5), we lag the MML indicator. The MML lags are jointly significant and are, without exception, negative. However, there is evidence that the impact of legalization eventually wanes. The first full year after coming into effect, legalization is associated with an 8 to 11 percent reduction in the fatality rate. ${ }^{21}$ The estimated coefficients increase in absolute magnitude until the fourth full year after legalization, when there is a 10 to 13 percent reduction in the fatality rate. After 5 years, the reduction is between 4 and 10 percent and only significant when the state-specific linear time trends are omitted. In the final column of Table 5, we add a series of MML leads to the model. Consistent with the graphical evidence in Figures 1-3, their estimated coefficients are small and jointly insignificant. In Table 6, we replace Fatalities Total $_{s t}$ with Fatalities (No Alcohol) st $_{\text {, Fatalities }(B A C>}$ $0)_{s t}$, and Fatalities $(B A C \geq 0.10)_{s t}$. The results suggest that MMLs are related to traffic fatalities through the consumption of alcohol. The estimate of $\beta_{1}$ is negative when fatalities not involving alcohol are considered, but it is relatively small and statistically indistinguishable from zero. In contrast, the legalization of medical marijuana is associated with a 13.2 percent decrease in fatalities involving alcohol, and a 15.5 percent decrease in fatalities resulting from accidents in which at least one driver had a BAC over 0.10. Lagging the MML indicator produces a similar

\footnotetext{
${ }^{21}$ In comparison, Dee (1999) found that increasing the minimum legal drinking age (MLDA) to 21 reduced traffic fatalities by at least 9 percent among 18- through 20-year-olds. Kaestner and Yarnoff (2011) analyzed the long-term effects of MLDA laws. They found that raising the MLDA to 21 was associated with a 10 percent reduction in traffic fatalities among adult males. Carpenter and Stehr (2008) found that mandatory seatbelt laws decreased traffic fatalities among 14- through 18-year-olds by approximately 8 percent; Dee et al. (2005) found that graduated driver licensing laws decreased traffic fatalities among 15-through 17-year-olds by nearly 6 percent. Because all states raised their MLDA to 21 prior to 1990, we do not include it as a control. However, our estimates suggest that mandatory seatbelt laws decrease traffic fatalities among 15- through 19-year-olds by approximately 11 percent, and graduated driver licensing laws decrease traffic fatalities among 15- through 19-year-olds by approximately 6 percent. While the estimated relationship between $0.08 \mathrm{BAC}$ laws and traffic fatalities is generally negative and often large, it is never statistically significant at conventional levels. This is consistent with the results of Young and Bielinska-Kwapisz (2006) and Freeman (2007) who found little evidence that 0.08 BAC laws reduced traffic fatalities. Finally, consistent with the results of Grant (2010), we find little evidence that Zero Tolerance laws reduce traffic fatalities.
} 
pattern of results: the MML lags jointly predict crashes involving alcohol, but are insignificant in the Fatalities (No Alcohol) st $_{\text {equation. }}{ }^{22}$

Table 7 provides additional evidence with regard to the role of alcohol consumption. The first two columns of Table 7 show the relationship between MMLs and traffic fatalities occurring on weekdays as compared to the weekend, when the consumption of alcohol rises (Haines et al. 2003). Legalization is associated with an 8.0 percent decrease in the weekday traffic fatality rate; in comparison, it is associated with a 10.9 percent decrease in the weekend traffic fatality rate. The former estimate is not significant at conventional levels, while the latter is significant at the 10 percent level. $^{23}$

The remaining columns of Table 7 show the relationship between MMLs and traffic fatalities occurring during the day as compared to at night, when fatal crashes are more likely to involve alcohol (Dee 1999). Legalization is associated with a 7.3 percent decrease in the daytime traffic fatality rate; in comparison, it is associated with an 11.0 percent decrease in the nighttime traffic fatality rate. The former estimate is not significant at conventional levels, while the latter is significant at the 10 percent level. $^{24}$

Table 8 presents estimates of the relationship between MMLs and traffic fatalities by age. Among 15-through 19-year-olds, the estimate of $\beta_{1}$ is negative, but is small in magnitude and statistically insignificant. However, legalization is associated with a 16.7 percent decrease in the

\footnotetext{
${ }^{22}$ Restricting our attention to crashes in which at least one driver had a BAC greater than 0 , legalization is associated with a (statistically insignificant) 11.6 percent decrease in fatalities among drunk drivers $(\mathrm{BAC}>0)$ and their passengers. This estimate is similar in magnitude to the estimate in column (3) of Table 6. Nonetheless, we find evidence of third-party effects: legalization is associated with a 23.4 percent reduction in fatalities among sober drivers and their passengers, and a 19.9 percent reduction in fatalities among pedestrians, cyclists and individuals in other types of non-motorized vehicles.

${ }^{23}$ The hypothesis that these estimates are equal can be rejected at the 10 percent level.

${ }^{24}$ It should be noted, however, that we cannot formally reject the hypothesis that these estimates are equal.
} 
fatality rate of 20- through 29 year-olds, and a 16.1 percent decrease in the fatality rate of 30through 39-year-olds. Although registry data indicate that many medical marijuana patients are over the age of 40 , estimates of $\beta_{1}$ are smaller and statistically insignificant among 40- through 49-year-olds, 50- through 59-year-olds, and individuals over the age of 60.

Table 9 presents estimates of the relationship between MMLs and traffic fatalities by gender. They provide some evidence that MMLs have a greater impact on fatalities among males. Specifically, legalization is associated with a 10.8 percent decrease in the male traffic fatality rate as compared to a 6.9 percent decrease in the female fatality rate. The former estimate is significant at the 10 percent level, while the latter is not significant at conventional levels. ${ }^{25}$ This pattern of results is consistent with registry data showing that the majority of medical marijuana patients are male. ${ }^{26}$

\subsection{Tests of Endogeneity}

Until this point in the analysis, we have addressed the possibility that legalization went hand in hand with other behaviors or policies related to traffic fatalities by employing a rich set of controls. Table 10 presents our attempts to tackle the endogeneity issue head on.

\footnotetext{
${ }^{25}$ The hypothesis that these estimates are equal can be rejected at the 5 percent level. Appendix Tables $4 \mathrm{~A}$ and 4B present estimates of $\beta_{1}$ by age and gender. The estimated effect of legalization on traffic fatalities is largest among 20- through 29 -year-old males and 30- through 39-year-old females. There is evidence that legalization leads to reduced traffic fatalities among males over the age of 59.

${ }^{26}$ Roughly half of the states that have legalized medical marijuana permit collective cultivation, also known as "group growing." However, states such as Alaska, Hawaii, Maine, New Jersey, New Mexico and Vermont limit caregivers to one patient, prohibit collective cultivation by caregivers, or prohibit home cultivation altogether (Appendix Table 2). In these states, possession limits are easier to enforce, and illegal suppliers are easier to identify (Selecky 2008). Estimates available upon request suggest that the relationship between legalization and traffic fatalities is strongest when collective cultivation is permitted. Although negative, the estimated effect of legalization on traffic fatalities is smaller and statistically insignificant among states that prohibit collective cultivation.
} 
First, we ran a series of regressions in which placebo MMLs were randomly assigned to control states. ${ }^{27}$ Because 14 states and the District of Columbia legalized medical marijuana during the period 1990 through 2010, we assigned 15 placebos per trial. The estimated coefficient of the placebo MML was negative and statistically significant at the 10 percent level only 10 times out of 300 trials.

Next, we estimated the relationship between MMLs and traffic fatalities in which either tire or wheel failure was cited as a potential cause of the crash. Although road improvements, increased spending on road maintenance, and increased commercial vehicle inspections could reduce tire/wheel failure, we found little evidence of a relationship between legalization and this outcome. In fact, the estimated coefficient of the $M M L$ indicator was positive.

We also examined the relationship between MMLs and three variables that could have potentially influenced traffic fatalities: per capita police expenditures, per capita highway law enforcement expenditures, and per capita highway service and maintenance expenditures. ${ }^{28}$ Again, the results provided little evidence of policy endogeneity: the estimated coefficient of the $M M L$ indicator was small and insignificant in all three of these regressions.

Finally, we examined whether the policy variables included in the vector $\boldsymbol{X}_{\text {st }}$ predict the passage of MMLs. The results are reported in Table 11. In column (2) of Table 11, we focus on alcohol-related policies, such as the beer tax and whether a 0.08 BAC limit was in effect. In column (3) we include marijuana decriminalization and drug per se laws, which prohibit the

\footnotetext{
${ }^{27}$ This approach is similar that of Luallen (2006), who examined the relationship between teacher strike days and juvenile crime. Assignment of the placebo MML was based on random numbers drawn from the uniform distribution.

${ }^{28}$ The data on per capita police expenditures are from the Bureau of Justice Statistics. The data on per capita highway law enforcement expenditures and per capita highway service and maintenance expenditures are from Highway Statistics, an annual publication produced by the U.S. Department of Transportation. Data on police expenditures are not available for the years 2001, 2003, and 2010; data on highway expenditures are not available for the District of Columbia.
} 
operation of a motor vehicle with drugs (or drug metabolites) in the system. Neither the alcoholnor drug-related policies predict the legalization of medical marijuana. However, when the full set of policy variables is included, we find evidence of a negative relationship between banning the use of handheld cell phones while driving and the probability of legalizing medical marijuana (column 4). This result raises the possibility that other, more difficult-to-measure, polices affecting traffic fatalities may be related to legalization.

\section{MEDICAL MARIJUNA LAWS AND ALCOHOL CONSUMPTION}

\subsection{Evidence from the BRFSS}

In this section, we use individual-level data from the Behavioral Risk Factor Surveillance System (BRFSS) to examine the effects of MMLs on direct measures of alcohol consumption. Begun in 1984 and administered by state health departments in collaboration with the Centers for Disease Control, the BRFSS is designed to measure "behavioral risk factors" for the adult population (18 years of age or older). In 1993, the BRFSS was expanded to include all 50 states. As part of the core questionnaire, BRFSS respondents are asked:

1. Have you had any beer, wine, wine coolers, cocktails, or liquor during the past month?

2. During the past month, how many days per week or per month did you drink any alcoholic beverages, on the average?

3. On days when you drink, about how many drinks do you drink on average?

Using the answers to these questions, we constructed a variety of outcome variables, including:

Drank $>0$, an indicator for whether the respondent consumed alcohol in the past month; $30+$ Drinks, an indicator for whether the respondent had 30 or more drinks in the past month; $60+$ Drinks, an indicator for whether the respondent had 60 or more drinks in the past month; and 
Number of Drinks, equal to the number of drinks consumed in the past month conditional on drinking.

Table 12 presents estimates of the following equation by age group for the period 19932010:

$$
Y_{i s t}=\beta_{0}+\beta_{1} M M L_{i s t}+\boldsymbol{X}_{s t} \boldsymbol{\beta}_{2}+Z_{i s t} \boldsymbol{\beta}_{3}+v_{s}+w_{t}+\Theta_{s} \cdot t+\varepsilon_{i s t}
$$

where $Y_{\text {ist }}$ measures alcohol consumption, $\boldsymbol{X}_{\boldsymbol{s} t}$ is a vector of state-level controls, $\boldsymbol{Z}_{\text {ist }}$ is a vector of individual-level controls, and state-specific linear trends are represented by $\Theta_{s} \cdot t .^{29}$

The estimates in Table 12 offer additional support for the hypothesis that legalization reduces traffic fatalities through its impact on alcohol consumption. They are uniformly negative and often statistically significant at conventional levels. Moreover, the relationship between legalization and alcohol consumption appears to be strongest among young adults, the group for whom the relationship between legalization and traffic fatalities was strongest.

For instance, among 20- through 29-year-olds, legalization is associated with a 5.3 percent $(.031 / .589)$ reduction in the probability of having consumed alcohol in the past month, a 19.6 percent $(.011 / .056)$ reduction in the probability of having consumed $60+$ drinks, and a 10.6 percent (2.40/22.71) reduction in the number of drinks consumed (conditional on having had at least one drink). ${ }^{30}$ During the period 1990-2010, almost one fourth of individuals killed in traffic

\footnotetext{
${ }^{29}$ The vector $\boldsymbol{X}_{\boldsymbol{s} t}$ includes per capita income, the state unemployment rate, the beer tax, an indicator for whether a Zero Tolerance drunk driving law was in effect, and an indicator for whether a 0.08 BAC law was in effect. The vector $\boldsymbol{Z}_{\text {ist }}$ includes indicators for race, ethnicity, educational attainment, marital status, employment status, and the season in which the BRFSS interview took place.

${ }^{30}$ Descriptive statistics for the drinking outcomes are presented in Appendix Table 5.
} 
accidents, and more than one third of individuals killed in traffic accidents involving alcohol, were between the ages of 20 and $29 .^{31}$

BRFSS respondents are also asked how many times in the past month they binge drank, defined as having 5 or more alcoholic beverages on an occasion. ${ }^{32}$ The estimates in Table 12 suggest that the legalization of medical marijuana leads to sharp reductions in binge drinking, a form of alcohol abuse considered to have "particularly high social and economic costs" (Naimi et al. 2003, p. 70). Among 18- and 19-year-olds, legalization is associated with a 9.4 percent $(.018 / .192)$ reduction in the probability of binge drinking in the past month; among 40- through 49-year-olds, legalization is associated with an 8.8 percent $(.013 / .147)$ reduction in this probability. Among 20- through 29-year-olds, legalization is associated with a 7.4 percent $(.012 / .163)$ reduction in the probability of binge drinking at least twice in the past month.

\subsection{Evidence from alcohol sales}

Information on alcohol sales is collected by the Beer Institute and published annually in the Brewers Almanac. Data on per-capita beer sales (in gallons) are available for the period 1990-2010. Data on per-capita wine and spirits sales (in gallons) are available for the period 1994-2010. We use these data to estimate the relationship between legalization and alcohol consumption at the state level.

\footnotetext{
${ }^{31}$ Using data on 19- through 22-year-olds and a regression discontinuity design, Carpenter and Dobkin (2009) found that reaching the minimum legal drinking age was associated with a 21 percent increase in the number of days on which alcohol is consumed and a 15 percent increase in traffic fatalities. The implied elasticity from these estimates is 0.71 (i.e., 0.15/0.21). Restricting our sample to 19- through 22-year-olds, we find that the legalization of medical marijuana is associated with a 15.0 percent decrease in drinks consumed ( $\mathrm{p}$-value $=0.17)$ and a 12.2 percent decrease in traffic fatalities ( $\mathrm{p}$-value $=0.16$ ), for an implied elasticity of 0.81 (i.e., $0.122 / 0.150$ ).

${ }^{32}$ In 2006, the BRFSS began asking female respondents whether they had had 4 or more drinks on an occasion. Male respondents were asked whether they had had 5 or more drinks on an occasion throughout the period under study (1993-2010).
} 
The results, presented in the top panel of Table 13, are consistent with the hypothesis that marijuana and beer are substitutes. Specifically, legalization is associated with an almost 5 percent increase in the consumption of beer, the most popular beverage among 18- through 29year-olds (Jones 2008). ${ }^{33}$ Legalization is negatively related to wine sales, and positively related to spirits sales, but these estimates are not statistically significant.

Estimates of the relationship between beer consumption and traffic fatalities using $M M L$ as an instrument are presented in the bottom panel of Table $13 .{ }^{34} \mathrm{~A} 10$ percent increase in percapita beer sales is associated with a 17 percent increase in total fatalities. In comparison, using alcohol excise taxes as instruments, Young and Bielinska-Kwapisz (2006) found that a 10 percent increase in per-capita ethanol consumption led to an 11 percent increase in traffic fatalities. The difference in these estimates could reflect who, in effect, is being treated. Our analysis of the BRFSS data suggests that the relationship between legalization and alcohol consumption is strongest among young adults (a group prone to heavy drinking and responsible for a disproportionate share of traffic fatalities), while there is evidence that light and moderate drinkers are more responsive to increases in the price of alcohol than heavy drinkers (Manning et al. 1995). A 10 percent increase in per-capita beer sales is associated with a 24 percent increase in fatalities involving alcohol and a 32 percent increase in fatalities resulting from accidents in which at least one driver had a BAC greater than or equal to 0.10 .

\footnotetext{
33 These results help explain why the California Beer \& Beverage Distributors donated \$10,000 to Public Safety First, a committee organized to oppose a recent California initiative legalizing marijuana (Grim 2010).

${ }^{34}$ This empirical strategy is based on the assumption that legalization is related to traffic fatalities exclusively through beer consumption. Because the first-stage F-statistic for the null hypothesis that legalization is unrelated to beer consumption is less than 10, the standard proposed by Staiger and Stock (1997), the second-stage estimates should be interpreted cautiously.
} 


\section{CONCLUSION}

To date, 17 states and the District of Columbia have legalized medical marijuana.

Others are likely to follow. A recent Gallup poll found that 70 percent of Americans are in favor of "making marijuana legally available for doctors to prescribe in order to reduce pain and suffering" (Mendes 2010).

Despite intense public interest, medical marijuana laws have received little attention from researchers. In fact, next to nothing is known about their impact on outcomes of interest to policymakers, social scientists, advocates, and opponents.

The current study draws on data from a variety of sources to explore the effects of legalizing medical marijuana. Using information collected from back issues of High Times, a monthly magazine that advocates for the legalization of marijuana, we find that MMLs lead to a substantial decrease in the price of high-quality marijuana. Using data from the Fatality Analysis Reporting System (FARS) for the period 1990-2010, we find that traffic fatalities fall by 8 to 11 percent the first full year after legalization. Although registry data from Arizona and Montana suggest that more than half of medical marijuana patients are over the age of 40 , the estimated relationship between legalization and traffic fatalities is strongest among young adults.

Why does legalizing medical marijuana reduce traffic fatalities? Alcohol consumption appears to play a key role. The legalization of medical marijuana is associated with a 7.2 percent decrease in traffic fatalities in which there was no reported alcohol involvement, but this estimate is not statistically significant at conventional levels. In comparison, the legalization of medical marijuana is associated with a 13.2 percent decrease in fatalities in which at least one driver involved had a positive BAC level. 
The negative relationship between the legalization of medical marijuana and traffic fatalities involving alcohol lends support to the hypothesis that marijuana and alcohol are substitutes. In order to explore this hypothesis further, we examine the relationship between medical marijuana laws and alcohol consumption. We find that the legalization of medical marijuana is associated with reduced alcohol consumption, especially among young adults. Evidence from simulator and driving course studies provides a potential explanation for why substituting marijuana for alcohol could lead to fewer traffic fatalities. These studies show that alcohol consumption leads to an increased risk of collision (Kelly et al. 2004; Sewell et al. 2009). Even at low doses, drivers under the influence of alcohol tend to underestimate the degree to which they are impaired (MacDonald et al. 2008; Marczinski et al. 2008; Robbe and O'Hanlon 1993; Sewell et al. 2009), drive at faster speeds, and take more risks (Burian et al. 2002; Ronen et al. 2008; Sewell et al. 2009). In contrast, simulator and driving course studies provide only limited evidence that driving under the influence of marijuana leads to an increased risk of collision, perhaps as a result of compensatory driver behavior (Kelly et al. 2004; Sewell et al. 2009).

However, because other mechanisms cannot be ruled out, the negative relationship between medical marijuana laws and alcohol-related traffic fatalities does not necessarily imply that driving under the influence of marijuana is safer than driving under the influence of alcohol. For instance, it is possible that legalizing medical marijuana reduces traffic fatalities through its effect on substance use in public. Alcohol is often consumed in restaurants and bars, while many states prohibit the use of medical marijuana in public. ${ }^{35}$ Even where it is not explicitly

\footnotetext{
${ }^{35}$ For instance, in Colorado "the medical use of marijuana in plain view of, or in a place open to, the general public" is prohibited; in Connecticut, the smoking of marijuana is prohibited in "any public place"; in Oregon engaging "in the medical use of marijuana in a public place" is prohibited; and in Washington, it is a misdemeanor "to use or display medical marijuana in a manner or place which is open to the view of the general public." Although Montana
} 
prohibited, anecdotal evidence suggests that public use of medical marijuana can be controversial. $^{36}$ If marijuana consumption typically takes place at home, then designating a driver for the trip back from a restaurant or bar becomes unnecessary, and legalization could reduce traffic fatalities even if driving under the influence of marijuana is every bit as dangerous as driving under the influence of alcohol.

\section{Acknowledgements}

We would like to thank Dean Anderson, Brian Cadena, Christopher Carpenter, Chad Cotti, Scott Cunningham, Benjamin Crost, Brian Duncan, Andrew Friedson, Darren Grant, Mike Hanlon, Rosalie Pacula, Henri Pellerin, Claus Pörtner, Randy Rucker, Doug Young and seminar participants at Clemson University, Colorado State University, Cornell University, and the 2012 NBER Spring Health Economics Program Meeting for comments and suggestions.

\section{REFERENCES}

Adams, Jill. 2008. "Medical Marijuana Inspires Strong Opinions, But What Does Science Say?" Chicago Tribune. 18 August. Available at: http://www.chicagotribune.com/health/la-he-marijuana-adams182008aug18,0,2023647.story.

Adams, Tom. 2010. “Oregon Man Tests Whether Medical Marijuana Users Can Carry it in Public." KLEWTV.COM, March 16. Available at: http://www.klewtv.com/news/87968832.html.

Adams, Scott; Blackburn, McKinley and Chad Cotti. 2012. "Minimum Wages and AlcoholRelated Traffic Fatalities among Teens.” Forthcoming at Review of Economics and Statistics.

law prohibits the use of medical marijuana in parks, schools, public beaches and correctional facilities, it does not explicitly prohibit its use in other public places.

${ }^{36}$ See, for instance, Whitnell (2008), Adams (2010), Moore (2010), and Ricker (2010). 
Belville, Russ. 2011. “Oregon's Workplaces Safest Ever, Despite 40,000 Medical Marijuana Patients." Examiner. 6 June. Available at: http://www.examiner.com/medical-marijuana-dispensaries-in-portland/oregon-sworkplaces-safest-ever-despite-40-000-medical-marijuana-patients.

Bertrand, Marianne; Duflo, Esther and Sendhil Mullainathan. 2004. "How Much Should We Trust Differences-in-Differences Estimates? Quarterly Journal of Economics 119: 249276.

Bilz, Gregg. 1992. "The Medical Use of Marijuana: The Politics of Medicine." Hamline Journal of Public Law and Policy 13: 117-135.

Blankstein, Andrew. 2010. "LAPD Investigates Third Shooting at a Medical Marijuana Dispensary." Los Angeles Times. 1 July. Available at: http://articles.latimes.com/2010/jul/01/local/la-me-pot-shooting-20100701.

Burian, Scott; Liguori, Anthony and John Robinson. 2002. "Effects of Alcohol on Risk-Taking During Simulated Driving." Human Psychopharmacology 17: 141-150.

Brittain, Amy. 2012. "Medical Marijuana Boss: Gov. Christie's Pot Program Delay is Sabotage." The Star Ledger, March 23. Available at: http://www.nj.com/news/index.ssf/2012/03/medicial_marijuana_boss_gov_ch.html

Carpenter, Christopher. 2004. "How do Zero Tolerance Drunk Driving Laws Work?" Journal of Health Economics 23: 61-83.

Carpenter, Christopher and Carlos Dobkin. 2009. "The Effect of Alcohol Consumption on Mortality: Regression Discontinuity Evidence from the Minimum Drinking Age." American Economic Journal: Applied Economics 1: 164-182.

Carpenter, Christopher and Mark Stehr. 2008. "The Effects of Mandatory Seatbelt Laws on Seatbelt Use, Motor Vehicle Fatalities, and Crash-Related Injuries among Youths." Journal of Health Economics 27: 642-662.

Centers for Disease Control and Prevention. 2010. Web-based Injury Statistics Query and Reporting System. Atlanta, GA: U.S. Department of Health and Human Services, CDC. Available at: http://www.cdc.gov/injury/wisqars.

Chaloupka, Frank; Saffer, Henry and Michael Grossman. 1991. "Alcohol Control Policies and Motor Vehicle Fatalities.” NBER Working Paper No. 3831.

Chaloupka, Frank and Adit Laixuthai. 1997. "Do Youths Substitute Alcohol and Marijuana? Some Econometric Evidence.” Eastern Economic Journal 23: 253-275.

Cochran, Diane. 2010. "Medical Marijuana Card OK'd After 8 Minutes, 6 Questions.” Billings Gazette. 21 August. Available at: 
http://billingsgazette.com/article_873a0ad2-adaf-11df-8799-001cc4c002e0.html.

Cohen, Alma and Liran Einav. 2003. "The Effects of Mandatory Seat Belt Laws on Driving Behavior and Traffic Fatalities." Review of Economics and Statistics 85: 828-843.

Corry, Jessica; Davis, Lauren; Corry, Jr., Robert and Bob Hoban. 2009. "Setting the Facts Straight on Medical Marijuana Statistics." Denver Post, 19 December. Available at: http://www.denverpost.com/headlines/ci_14027740.

Crombie, Noelle. 2012. "Cracks in Oregon's Medical Marijuana Law are Filled with Weed." The Oregonian. 21 April. Available at:

http://www.oregonlive.com/health/index.ssf/2012/04/cracks_in_oregons_medical_mari.ht $\underline{\mathrm{ml}}$.

Crost, Benjamin and Santiago Guerrero. 2012. "The Effect of Alcohol Availability on Marijuana Use: Evidence from the Minimum Legal Drinking Age.” Journal of Health Economics 31: 112-121.

Crost, Benjamin and Daniel I. Rees. Forthcoming. "The Minimum Legal Drinking Age and Marijuana Use: New Estimates from the NLSY97.” Journal of Health Economics.

Dee, Thomas. 1999. "State Alcohol Policies, Teen Drinking and Traffic Fatalities." Journal of Public Economics 72: 289-315.

Dee, Thomas. 2001. "Does Setting Limits Save Lives? The Case of 0.08 BAC Laws." Journal of Policy Analysis and Management 20: 111-128.

Dee, Thomas and Rebecca Sela. 2003. "The Fatality Effects of Highway Speed Limits by Gender and Age." Economics Letters 79: 401-408.

Dee, Thomas; Grabowski, David and Michael Morrisey. 2005. "Graduated Driver Licensing and Teen Traffic Fatalities.” Journal of Health Economics 24: 571-589.

Deitch, Robert. 2003. Hemp - American History Revisited. New York, NY: Algora Publishing.

Dills, Angela. 2010. "Social Host Liability for Minors and Underage Drunk-Driving Accidents." Journal of Health Economics 29: 241-249.

DiNardo, John and Thomas Lemieux. 2001. "Alcohol, Marijuana, and American Youth: The Unintended Consequences of Government Regulation." Journal of Health Economics 20: $991-1010$.

Eddy, Mark. 2010. "Medical Marijuana: Review and Analysis of Federal and State Policies." Congressional Research Service Report for Congress. Available at: http://www.fas.org/sgp/crs/misc/RL33211.pdf. 
Eisenberg, Daniel. 2003. "Evaluating the Effectiveness of Policies Related to Drunk Driving." Journal of Policy Analysis and Management 22: 249-274.

Farmer, Charles; Retting, Richard and Adrian Lund. "Changes in Motor Vehicle Occupant Fatalities After Repeal of the National Maximum Speed Limit." Accident Analysis and Prevention 31: 537-543.

Farrelly, Matthew; Bray, Jeremy; Zarkin, Gary; Wendling, Brett and Rosalie Pacula. 1999. "The Effects of Prices and Policies on the Demand for Marijuana: Evidence from the National Household Surveys on Drug Abuse.” NBER Working Paper No. 6940.

Florio, Gwen. 2011. "Kids' Use of Medical Marijuana Stirs Debate Over Future in Montana." Missoulian. 27 March. Available at: http://missoulian.com/news/local/article_fe14a69c-5833-11e0-9593-001cc4c002e0.html.

Freeman, Donald. 2007. "Drunk Driving Legislation and Traffic Fatalities: New Evidence on BAC 08 Laws." Contemporary Economic Policy 25: 293-308.

Gieringer, Dale.1999. "The Forgotten Origins of Cannabis Prohibition in California." Contemporary Drug Problems 26: 237-288.

Gorman, Dennis M. and J. Charles Huber Jr. 2007. "Do Medical Cannabis Laws Encourage Cannabis Use?” International Journal of Drug Policy 18:160-167.

Grant, Darren. 2010. "Dead on Arrival: Zero Tolerance Laws Don’t Work.” Economic Inquiry 48: $756-770$.

Greenstone, Michael. 2002. "A Reexamination of Resource Allocation Responses to the 65-mph Speed Limit.” Economic Inquiry 40: 271-278.

Grim, Ryan. 2010. "California Pot Initiative Opposed By Beer Industry." The Huffington Post. 21 September. Available at: http://www.huffingtonpost.com/2010/09/21/this-buds-not-for-you-bee_n_732901.html.

Haines, Pamela; Hama, Mary; Guilkey, David and Barry M. Popkin. 2003. "Weekend Eating in the United States is Linked with Greater Energy, Fat, and Alcohol Intake." Obesity Research 11: 945-949.

Harper, Sam; Strumpf, Erin and Jay Kaufman. 2012. "Do Medical Marijuana Laws Increase Marijuana Use? Replication Study and Extension.” Annals of Epidemiology 22: 207-212.

Hoeffel, John. 2011. "Rand Study Finds Less Crime Near Pot Dispensaries.” Los Angeles Times, 21 September. Available at: http://articles.latimes.com/2011/sep/21/local/la-me-0928-marijuana-dispensaries$\underline{20110921 .}$. 
Jacobson, Mireille. 2004. "Baby Booms and Drug Busts: Trends in Youth Drug Use in the United States, 1975-2000.” Quarterly Journal of Economics 119: 1481-1512.

Jacobson, Mireille; Chang, Tom; Anderson, James; MacDonald, John; Bluthenthal, Ricky and Scott Ashwood. 2011. "Regulating Medical Marijuana Dispensaries: An Overview with Preliminary Evidence of Their Impact on Crime.” RAND Technical Report.

Jones, Jeffrey M. 2008. "Beer Back to Double-Digit Lead Over Wine as Favored Drink." Gallup. 25 July. Available at: http://www.gallup.com/poll/109066/beer-backdoubledigit-lead-over-wine-favored-drink.aspx

Jones, Reese and George Stone. 1970. "Psychological Studies of Marijuana and Alcohol in Man.” Psychopharmacologia 18: 108-117.

Kaestner, Robert and Benjamin Yarnoff. 2011. "Long-Term Effects of Minimum Drinking Age Laws on Adult Alcohol Use and Driving Fatalities." Journal of Law and Economics 54: 365-388.

Kelly, Erin; Darke, Shane and Joanne Ross. 2004. "A Review of Drug Use and Driving: Epidemiology, Impairment, Risk Factors and Risk Perceptions.” Drug and Alcohol Review 23: 319-344.

Kolko, Jed. 2009. "The Effects of Mobile Phones and Hands-Free Laws on Traffic Fatalities." B.E. Journal of Economic Analysis and Policy (Contributions) 9: 1-26.

Lamoureux, Shannon. 2011. "State Medical Marijuana Laws Have Not Increased Teen Marijuana Use.” Colorado Dispensary Services, 3 July. Available at: http://www.cdscenters.com/blog/2011/07/03/state-medical-marijuana-laws-have-notincreased-teen-marijuana-use/.

Ledolter, Johannes and K.S. Chan. 1996. "Evaluating the Impact of the $65 \mathrm{mph}$ Maximum Speed Limit on Iowa Rural Interstates.” American Statistician 50: 79-85.

Liang, Lan and Jidong Huang. 2008. "Go Out or Stay In? The Effects of Zero Tolerance Laws on Alcohol Use and Drinking and Driving Patterns among College Students." Health Economics 17: 1261-1275.

Luallen, Jeremy. 2006. "School's Out...Forever: A Study of Juvenile Crime, At-Risk Youths and Teacher Strikes." Journal of Urban Economics 59: 75-103.

MacDonald, Scott; Mann, Robert; Chipman, Mary; Pakula, Basia; Erickson, Pat; Hathaway, Andrew and Peter MacIntyre. 2008. "Driving Behavior Under the Influence of Cannabis or Cocaine.” Traffic Injury Prevention 9: 190-194.

Manning, Willard; Blumberg, Linda and Lawrence Moulton. 1995. "The Demand for Alcohol: The Differential Response to Price." Journal of Health Economics 14: 123-148. 
Marczinski, Cecile; Harrison, Emily and Mark Fillmore. 2008. "Effects of Alcohol on Simulated Driving and Perceived Driving Impairment in Binge Drinkers." Alcoholism: Clinical and Experimental Research 32: 1329-1337.

Marijuana Policy Project. 2011. "Key Aspects of State and D.C. Medical Marijuana Laws." Available at: http://www.mpp.org/legislation/state-by-state-medical-marijuana-laws.html.

Marks, David and Michael MacAvoy. 1989. "Divided Attention Performance in Cannabis Users and Non-Users Following Alcohol and Cannabis Separately and in Combination." Psychopharmacology 99: 397-401.

Marmor, Jane. 1998. “Medical Marijuana.” Western Journal of Medicine 168: 540-543.

McLaren, Jennifer; Swift, Wendy; Dillon, Paul and Steve Allsop. 2008. "Cannabis Potency and Contamination: A Review of the Literature." Addiction 103: 100-1109.

Mendes, Elizabeth. 2010. "New High of 46\% of Americans Support Legalizing Marijuana." Gallup, October 28. Available at: http://www.gallup.com/poll/144086/New-High-Americans-Support-LegalizingMarijuana.aspx.

Model, Karyn. 1993. "The Effect of Marijuana Decriminalization on Hospital Emergency Room Drug Episodes: 1975-1978." Journal of the American Statistical Association 88: 737-747.

Moore, Michael. 2010. "Lighting Up: Rules Vague on Using Medical Marijuana in Public.” Missoulian. June 1. Available at: http://missoulian.com/news/local/article_540ae92c-6d38-11df-9db9-001cc4c03286.html.

Montgomery, Michael. 2010. "Plummeting Marijuana Prices Create a Panic in California" All Things Considered. 15 May. Available at: http://www.npr.org/templates/story/story.php?storyId=126806429\&ps=rs.

Naimi, Timothy; Brewer, Robert; Mokdad, Ali; Denny, Clark; Serdula, Mary and James Marks. 2003. "Binge Drinking among U.S. Adults.” JAMA 289: 70-75.

National Highway Traffic Safety Administration. 2010. "Drug Per Se Laws: A Review of Their Use in States." U.S. Department of Transportation.

Nisbet, Charles and Firouz Vakil. 1972. "Some Estimates of the Price and Expenditure Elasticities of Demand for Marijuana among U.C.L.A. Students." Review of Economics and Statistics 54: 473-475.

Pacula, Rosalie. 1998. "Does Increasing the Beer Tax Reduce Marijuana Consumption?" Journal of Health Economics 17: 557-585. 
Pacula, Rosalie; Grossman, Michael; Chaloupka, Frank; O’Malley, Patrick; Johnston, Lloyd and Matthew Farrelly. 2001. "Marijuana and Youth." In Jonathan Gruber, ed., Risky Behavior among Youths: An Economic Analysis. Chicago, IL: University of Chicago Press.

Pacula, Rosalie; Chriqui, Jamie; Reichmann, Deborah and Yvonne Terry-McElrath. 2002. "State Medical Marijuana Laws: Understanding the Laws and their Limitations." Journal of Public Health Policy 23: 413-439.

Pacula, Rosalie; Kilmer, Beau; Grossman, Michael and Frank Chaloupka. 2010. "Risks and Prices: The Role of User Sanctions in Marijuana Markets." B.E. Journal of Economic Analysis and Policy (Contributions) 10: 1-36.

Ricker, Amanda. 2010. "Bozeman Medical Marijuana Ordinance Takes Effect.” Bozeman Daily Chronicle, August 25. Available at:

http://www.bozemandailychronicle.com/news/article_f6394d6c-afda-11df-ba34$001 \mathrm{cc} 4 \mathrm{c} 002 \mathrm{e} 0 . \mathrm{html}$

Robbe, Hindrick and James O'Hanlon. 1993. "Marijuana and Actual Driving Performance." Washington, D.C.: U.S. Department of Transportation, National Highway Traffic Safety Administration.

Ronen, Adi; Gershon, Pnina; Drobiner, Hana; Rabinovich, Alex; Bar-Hamburger, Rachel; Mechoulam, Raphael; Cassuto, Yair and David Shinar. 2008. "Effects of THC on Driving Performance, Physiological State and Subjective Feelings Relative to Alcohol." Accident Analysis and Prevention 40: 926-934.

Ruhm, Christopher.1996. "Alcohol Policies and Highway Vehicle Fatalities.” Journal of Health Economics 15: 435-454.

Saffer, Henry and Frank Chaloupka. 1999. "The Demand for Illicit Drugs." Economic Inquiry 37: 401-411.

Scott, Emilee Mooney. 2010. "Marijuana Decriminalization.” Office of Legislative Research Report. Available at: http://www.cga.ct.gov/2010/rpt/2010-R-0204.htm.

Sewell, R. Andrew; Poling, James and Mehmet Sofuoglu. 2009. "The Effect of Cannabis Compared with Alcohol on Driving." American Journal on Addictions 18:185-193.

Selecky, Mary. 2008. "Patient Access to Medical Marijuana in Washington State." Washington State Department of Health, Publication Number 631-001.

Smith, Phillip. 2011. "Montana Medical Marijuana Industry Fights Back.” Stop the Drug War. 11 May. Available at: http://stopthedrugwar.org/topics/drug_war_issues/intersecting_issues/business?page=1. 
Smith, Phillip. 2012. "Feds Threaten Colorado Medical Marijuana Dispensaries." Stop the Drug War. 12 January. Available at: http://stopthedrugwar.org/chronicle/2012/jan/12/feds_threaten_colorado_medical_m.

Staiger, Douglas and James Stock. 1997. "Instrumental Variables Regression with Weak Instruments" Econometrica 65: 557-586.

Sun, Lena. 2010. "Dispensing Medical Pot a Challenge for Doctors." San Francisco Chronicle. 6 May. Available at: http://www.sfgate.com/health/article/Dispensing-medical-pot-a-challenge-for-doctors3189737.php.

Toplikar, Dave. 2012. "Medical Marijuana Issue Tangled in Courts, Legislature.” The Las Vegas Sun Times. 9 July. Available at: http://www.lasvegassun.com/news/2012/jul/09/medical-pot-issue-still-tangled-courts/.

Thurstone, Christian; Lieberman, Shane and Sarah Schmiege. 2011. "Medical Marijuana Diversion and Associated Problems in Adolescent Substance Treatment." Drug and Alcohol Dependence 118: 489-492.

U.K. Cannabis Campaign. 2011. "A Chronology of Cannabis." Available at: http://www.ccguide.org/chronol.php.

Wall, Melani; Poh, Ernest; Cerdá Magdalena; Keyes, Katherine; Galea, Sandro, and Deborah Hasin. 2011. "Adolescent Marijuana Use from 2002 to 2008: Higher in States with Medical Marijuana Laws, Cause Still Unclear." Annals of Epidemiology 21: 714716.

Watson, Stanley; Benson, Jr., John and Janet Joy. 2000. "Marijuana and Medicine: Assessing the Science Base." Archives of General Psychiatry 57: 547-552.

Wirfs-Brock, Jordan; Seaton, Lauren and Andrea Sutherland. 2010. "Colorado Medical Marijuana Surplus Leaks to Black Market.” Boulder Daily Camera. 31 July. Available at: http://www.dailycamera.com/news/ci_15644376.

Whitnell, Tim. 2008. "Human Rights Tribunal of Ontario to Decide Medical Marijuana Case. Sports Bar Owner Pitted against Former Customer." The Burlington Post, February 10. Available at: http://www.insidehalton.com/news/article/477905--human-rights-tribunal-of-ontario-todecide-medical-marijuana-case.

Williams, Jenny; Pacula, Rosalie; Chaloupka, Frank and Henry Wechsler. 2004. "Alcohol and Marijuana Use among College Students: Economic Complements or Substitutes?" Health Economics 13: 825-843.

Wright, Kay and Philip Terry. 2002. "Modulation of the Effects of Alcohol on Driving-Related Psychomotor Skills by Chronic Exposure to Cannabis." Psychopharmacology 160: 213- 
219.

Yörük, Bariş and Ceren Yörük. 2011. "The Impact of Minimum Legal Drinking Age Laws on Alcohol Consumption and Marijuana Use: Evidence from a Regression Discontinuity Design Using Exact Date of Birth.” Journal of Health Economics 30: 740-753.

Young, Douglas and Thomas Likens. 2000. "Alcohol Regulation and Auto Fatalities." International Review of Law and Economics 20: 107-126.

Young, Douglas and Agnieszka Bielinska-Kwapisz. 2006. "Alcohol Prices, Consumption, and Traffic Fatalities.” Southern Economic Journal 72: 690-703. 
Table 1. Medical Marijuana Laws, 1990-2010

Effective date

\begin{tabular}{ll}
\hline Alaska & Effective date \\
California & March 4, 1999 \\
Colorado & November 6, 1996 \\
District of Columbia & June 1, 2001 \\
Hawaii & July 27, 2010 \\
Maine & December 28, 2000 \\
Michigan & December 22, 1999 \\
Montana & December 4, 2008 \\
Nevada & November 2, 2004 \\
New Jersey & October 1, 2001 \\
New Mexico & October 1, 2010 \\
Oregon & July 1, 2007 \\
Rhode Island & December 3, 1998 \\
Vermont & January 3, 2006 \\
Washington & July 1, 2004 \\
Note: Medical marijuana laws came into effect in Arizona, Connecticut and Delaware after 2010.
\end{tabular}


Table 2A. Medical Marijuana Laws and the Price of High-Quality Marijuana, 1990-2011

\begin{tabular}{|c|c|c|c|c|c|}
\hline & (1) & (2) & (3) & $(4)$ & $(5)$ \\
\hline MML & $\begin{array}{l}-0.304 * * * \\
(0.037)\end{array}$ & $\begin{array}{l}-0.103^{*} \\
(0.058)\end{array}$ & $\ldots$ & $\ldots$ & \\
\hline 3 years before MML & $\ldots$ & $\ldots$ & $\ldots$ & $\ldots$ & $\begin{array}{c}0.022 \\
(0.074)\end{array}$ \\
\hline 2 years before MML & $\cdots$ & $\cdots$ & $\cdots$ & $\ldots$ & $\begin{array}{c}0.003 \\
(0.075)\end{array}$ \\
\hline 1 year before MML & $\ldots$ & $\ldots$ & $\ldots$ & $\ldots$ & $\begin{array}{l}-0.037 \\
(0.076)\end{array}$ \\
\hline Year of law change & $\ldots$ & $\ldots$ & $\begin{array}{l}-0.117 * \\
(0.061)\end{array}$ & $\begin{array}{l}-0.059 \\
(0.069)\end{array}$ & $\begin{array}{l}-0.060 \\
(0.096)\end{array}$ \\
\hline 1 year after MML & $\cdots$ & $\ldots$ & $\begin{array}{l}-0.156^{* * * *} \\
(0.044)\end{array}$ & $\begin{array}{l}-0.082 \\
(0.070)\end{array}$ & $\begin{array}{l}-0.084 \\
(0.097)\end{array}$ \\
\hline 2 years after MML & $\ldots$ & $\ldots$ & $\begin{array}{l}-0.203 * * * \\
(0.074)\end{array}$ & $\begin{array}{l}-0.110 \\
(0.082)\end{array}$ & $\begin{array}{l}-0.113 \\
(0.120)\end{array}$ \\
\hline 3 years after MML & $\ldots$ & $\ldots$ & $\begin{array}{l}-0.211 \text { *** } \\
(0.062)\end{array}$ & $\begin{array}{l}-0.128 \\
(0.084)\end{array}$ & $\begin{array}{l}-0.130 \\
(0.118)\end{array}$ \\
\hline 4 years after MML & $\cdots$ & $\cdots$ & $\begin{array}{l}-0.387 * * * \\
(0.123)\end{array}$ & $\begin{array}{l}-0.283 * * \\
(0.115)\end{array}$ & $\begin{array}{l}-0.286^{* *} \\
(0.125)\end{array}$ \\
\hline 5+ years after MML & $\cdots$ & $\cdots$ & $\begin{array}{l}-0.439 * * * \\
(0.048)\end{array}$ & $\begin{array}{l}-0.257 * * \\
(0.116)\end{array}$ & $\begin{array}{l}-0.262^{*} \\
(0.145)\end{array}$ \\
\hline $\mathrm{N}$ & 920 & 920 & 920 & 920 & 920 \\
\hline $\mathrm{R}^{2}$ & 0.224 & 0.310 & 0.241 & 0.315 & 0.315 \\
\hline Year FEs & Yes & Yes & Yes & Yes & Yes \\
\hline State FEs & Yes & Yes & Yes & Yes & Yes \\
\hline State covariates & Yes & Yes & Yes & Yes & Yes \\
\hline State-specific trends & No & Yes & No & Yes & Yes \\
\hline
\end{tabular}

*Statistically significant at $10 \%$ level; **at $5 \%$ level; ***at $1 \%$ level.

Notes: Each column represents the results from a separate regression. The dependent variable is equal to the natural $\log$ of the median price of marijuana in state $s$ and year $t$. The covariates are listed in Appendix Table 3. Standard errors, corrected for clustering at the state level, are in parentheses. 
Table 2B. Medical Marijuana Laws and the Price of Low-Quality Marijuana, 1990-2011

\begin{tabular}{|c|c|c|c|c|c|}
\hline 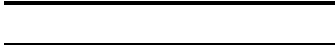 & (1) & $(2)$ & (3) & (4) & $(5)$ \\
\hline MML & $\begin{array}{l}-0.096 \\
(0.105)\end{array}$ & $\begin{array}{l}-0.075 \\
(0.150)\end{array}$ & $\ldots$ & $\ldots$ & $\ldots$ \\
\hline 3 years before MML & $\ldots$ & $\ldots$ & $\ldots$ & $\ldots$ & $\begin{array}{l}0.135 \\
(0.197)\end{array}$ \\
\hline 2 years before $\mathrm{MML}$ & $\ldots$ & $\ldots$ & $\ldots$ & $\ldots$ & $\begin{array}{l}0.103 \\
(0.108)\end{array}$ \\
\hline 1 year before MML & $\ldots$ & $\ldots$ & $\ldots$ & $\ldots$ & $\begin{array}{l}-0.088 \\
(0.200)\end{array}$ \\
\hline Year of law change & $\ldots$ & $\ldots$ & $\begin{array}{l}-0.035 \\
(0.154)\end{array}$ & $\begin{array}{l}-0.056 \\
(0.193)\end{array}$ & $\begin{array}{l}-0.013 \\
(0.196)\end{array}$ \\
\hline 1 year after MML & $\ldots$ & $\ldots$ & $\begin{array}{l}-0.250 * \\
(0.146)\end{array}$ & $\begin{array}{l}-0.182 \\
(0.176)\end{array}$ & $\begin{array}{l}-0.106 \\
(0.136)\end{array}$ \\
\hline 2 years after MML & $\ldots$ & $\ldots$ & $\begin{array}{l}-0.058 \\
(0.176)\end{array}$ & $\begin{array}{l}-0.016 \\
(0.190)\end{array}$ & $\begin{array}{c}0.053 \\
(0.166)\end{array}$ \\
\hline 3 years after MML & $\cdots$ & $\ldots$ & $\begin{array}{l}-0.244 * * \\
(0.098)\end{array}$ & $\begin{array}{l}-0.114 \\
(0.141)\end{array}$ & $\begin{array}{l}-0.028 \\
(0.138)\end{array}$ \\
\hline 4 years after MML & $\ldots$ & $\ldots$ & $\begin{array}{c}0.032 \\
(0.403)\end{array}$ & $\begin{array}{c}0.046 \\
(0.373)\end{array}$ & $\begin{array}{c}0.131 \\
(0.429)\end{array}$ \\
\hline 5+ years after MML & $\ldots$ & $\ldots$ & $\begin{array}{l}-0.038 \\
(0.073)\end{array}$ & $\begin{array}{c}0.271 \\
(0.335)\end{array}$ & $\begin{array}{c}0.370 \\
(0.267)\end{array}$ \\
\hline $\mathrm{N}$ & 483 & 483 & 483 & 483 & 483 \\
\hline $\mathrm{R}^{2}$ & 0.720 & 0.748 & 0.723 & 0.751 & 0.753 \\
\hline Year FEs & Yes & Yes & Yes & Yes & Yes \\
\hline State FEs & Yes & Yes & Yes & Yes & Yes \\
\hline State covariates & Yes & Yes & Yes & Yes & Yes \\
\hline State-specific trends & No & Yes & No & Yes & Yes \\
\hline
\end{tabular}

*Statistically significant at $10 \%$ level; **at $5 \%$ level; ***at $1 \%$ level.

Notes: Each column represents the results from a separate regression. The dependent variable is equal to the natural $\log$ of the median price of marijuana in state $s$ and year $t$. The covariates are listed in Appendix Table 3. Standard errors, corrected for clustering at the state level, are in parentheses. 
Table 3. Descriptive Statistics for FARS Analysis (Dependent Variables)

\begin{tabular}{|c|c|c|}
\hline Variable & Mean (SD) & Description \\
\hline Fatalities Total & $14.58(5.05)$ & Number of fatalities per 100,000 population \\
\hline $\begin{array}{l}\text { Fatalities } \\
(\text { No Alcohol) }\end{array}$ & $9.67(3.45)$ & $\begin{array}{l}\text { Number of fatalities per } 100,000 \text { population with no } \\
\text { indication of alcohol involvement }\end{array}$ \\
\hline $\begin{array}{l}\text { Fatalities } \\
(B A C>0)\end{array}$ & $3.97(1.74)$ & $\begin{array}{l}\text { Number of fatalities per } 100,000 \text { population where } \\
\text { at least one driver involved had a BAC }>0.00\end{array}$ \\
\hline $\begin{array}{l}\text { Fatalities } \\
(B A C \geq 0.10)\end{array}$ & $3.13(1.43)$ & $\begin{array}{l}\text { Number of fatalities per } 100,000 \text { population where } \\
\text { at least one driver involved had a BAC } \geq 0.10\end{array}$ \\
\hline Variable & Mean (SD) & Denominator \\
\hline $\begin{array}{l}\text { Fatalities, } \\
15-19 \text { year-olds }\end{array}$ & $24.55(9.75)$ & per 100,00015 - through 19 -year-olds \\
\hline $\begin{array}{l}\text { Fatalities, } \\
20-29 \text { year-olds }\end{array}$ & $23.59(8.41)$ & per 100,000 20- through 29-year-olds \\
\hline $\begin{array}{l}\text { Fatalities, } \\
\text { 30-39 year-olds }\end{array}$ & $15.45(6.49)$ & per 100,00030 - through 39 -year-olds \\
\hline $\begin{array}{l}\text { Fatalities, } \\
40-49 \text { year-olds }\end{array}$ & $14.00(5.63)$ & per 100,00040 - through 49 -year-olds \\
\hline $\begin{array}{l}\text { Fatalities, } \\
50-59 \text { year-olds }\end{array}$ & $13.22(4.93)$ & per 100,00050 - through 59 -year-olds \\
\hline $\begin{array}{l}\text { Fatalities, } \\
60 \text { plus }\end{array}$ & $17.39(5.28)$ & per 100,00060 -year-olds and above \\
\hline Fatalities males & $20.48(7.15)$ & per 100,000 males \\
\hline Fatalities females & $9.03(3.29)$ & per 100,000 females \\
\hline Fatalities weekdays & $8.32(2.88)$ & per 100,000 population \\
\hline Fatalities weekends & $6.22(2.25)$ & per 100,000 population \\
\hline Fatalities daytime & $7.04(2.59)$ & per 100,000 population \\
\hline Fatalities nighttime & $7.42(2.60)$ & per 100,000 population \\
\hline
\end{tabular}

Note: Weighted means based on the FARS state-level panel for 1990-2010. 
Table 4. Descriptive Statistics for FARS Analysis (Independent Variables)

\begin{tabular}{|c|c|c|}
\hline Variable & Mean (SD) & Description \\
\hline$M M L^{a}$ & $0.130(0.334)$ & $\begin{array}{l}=1 \text { if a state had a medical marijuana law in a given } \\
\text { year, }=0 \text { otherwise }\end{array}$ \\
\hline Mean age & $35.90(1.66)$ & Mean age of the state population \\
\hline Unemployment & $5.87(1.87)$ & State unemployment rate \\
\hline Income & $10.27(0.156)$ & $\begin{array}{l}\text { Natural logarithm of state real income per capita } \\
\text { (2000 dollars) }\end{array}$ \\
\hline Miles driven & $14.13(2.05)$ & $\begin{array}{l}\text { Vehicle miles driven per licensed driver } \\
\text { (thousands of miles) }\end{array}$ \\
\hline Decriminalized $^{a}$ & $0.330(0.470)$ & $\begin{array}{l}=1 \text { if a state had a marijuana decriminalization law } \\
\text { in a given year, }=0 \text { otherwise }\end{array}$ \\
\hline Drug per se & $0.142(0.345)$ & $\begin{array}{l}=1 \text { if a state had a drug per se law in a given year, } \\
=0 \text { otherwise }\end{array}$ \\
\hline$G D L^{a}$ & $0.522(0.493)$ & $\begin{array}{l}=1 \text { if a state had a graduated driver licensing law } \\
\text { with an intermediate phase in a given year, }=0 \\
\text { otherwise }\end{array}$ \\
\hline Primary seatbelt ${ }^{a}$ & $0.461(0.494)$ & $\begin{array}{l}=1 \text { if a state had a primary seatbelt law in a given } \\
\text { year, }=0 \text { otherwise }\end{array}$ \\
\hline Secondary seatbelt ${ }^{a}$ & $0.518(0.494)$ & $\begin{array}{l}=1 \text { if a state had a secondary seatbelt law in a given } \\
\text { year, }=0 \text { otherwise }\end{array}$ \\
\hline$B A C 0.08^{a}$ & $0.584(0.485)$ & $\begin{array}{l}=1 \text { if a state had a } .08 \mathrm{BAC} \text { law in a given year, }=0 \\
\text { otherwise }\end{array}$ \\
\hline$A L R^{a}$ & $0.721(0.445)$ & $\begin{array}{l}=1 \text { if a state had an administrative license } \\
\text { revocation law in a given year, }=0 \text { otherwise }\end{array}$ \\
\hline Zero Tolerance ${ }^{a}$ & $0.763(0.417)$ & $\begin{array}{l}=1 \text { if a state had a "Zero Tolerance" drunk } \\
\text { driving law in a given year, }=0 \text { otherwise }\end{array}$ \\
\hline Beer tax & $0.245(0.207)$ & Real beer tax (2000 dollars) \\
\hline Speed 70 & $0.462(0.499)$ & $\begin{array}{l}=1 \text { if a state had a speed limit of } 70 \mathrm{mph} \text { or } \\
\text { greater in a given year, }=0 \text { otherwise }\end{array}$ \\
\hline Texting ban & $0.041(0.185)$ & $\begin{array}{l}=1 \text { if a state had a cell phone texting ban in a given } \\
\text { year, }=0 \text { otherwise }\end{array}$ \\
\hline Hands Free & $0.025(0.150)$ & $\begin{array}{l}=1 \text { if a state had a "Hands Free" cell phone law in a } \\
\text { given year, }=0 \text { otherwise }\end{array}$ \\
\hline
\end{tabular}

${ }^{\mathrm{a}}$ Takes on fractional values for the years in which laws changed.

Note: Weighted using state populations. 
Table 5. Medical Marijuana Laws and Traffic Fatalities, 1990-2010

\begin{tabular}{|c|c|c|c|c|c|}
\hline & $\begin{array}{c}(1) \\
\text { Fatalities } \\
\text { Total }\end{array}$ & $\begin{array}{c}(2) \\
\text { Fatalities } \\
\text { Total }\end{array}$ & $\begin{array}{c}(3) \\
\text { Fatalities } \\
\text { Total }\end{array}$ & $\begin{array}{c}\text { (4) } \\
\text { Fatalities } \\
\text { Total }\end{array}$ & $\begin{array}{c}(5) \\
\text { Fatalities } \\
\text { Total }\end{array}$ \\
\hline$\overline{\mathrm{MML}}$ & $\begin{array}{l}-0.110 * * * \\
(0.030)\end{array}$ & $\begin{array}{l}-0.098 \\
(0.065)\end{array}$ & $\ldots$ & $\ldots$ & 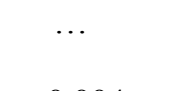 \\
\hline 3 years before MML & $\cdots$ & $\ldots$ & ... & ... & $\begin{array}{l}-0.004 \\
(0.018)\end{array}$ \\
\hline 2 years before MML & $\ldots$ & $\ldots$ & $\ldots$ & .. & $\begin{array}{l}-0.001 \\
(0.030)\end{array}$ \\
\hline 1 year before $\mathrm{MML}$ & ... & $\ldots$ & $\ldots$ & ... & $\begin{array}{l}-0.008 \\
(0.024)\end{array}$ \\
\hline Year of law change & ... & $\cdots$ & $\begin{array}{l}-0.049 * * \\
(0.023)\end{array}$ & $\begin{array}{l}-0.026 \\
(0.029)\end{array}$ & $\begin{array}{l}-0.029 \\
(0.028)\end{array}$ \\
\hline 1 year after MML & $\ldots$ & $\ldots$ & $\begin{array}{l}-0.115^{* * * *} \\
(0.036)\end{array}$ & $\begin{array}{l}-0.087^{*} \\
(0.051)\end{array}$ & $\begin{array}{l}-0.090^{*} \\
(0.048)\end{array}$ \\
\hline 2 years after MML & $\ldots$ & $\ldots$ & $\begin{array}{l}-0.125 * * \\
(0.059)\end{array}$ & $\begin{array}{l}-0.095 \\
(0.080)\end{array}$ & $\begin{array}{l}-0.099 \\
(0.074)\end{array}$ \\
\hline 3 years after MML & $\ldots$ & $\cdots$ & $\begin{array}{l}-0.137 * * * \\
(0.051)\end{array}$ & $\begin{array}{l}-0.107 \\
(0.071)\end{array}$ & $\begin{array}{l}-0.111^{*} \\
(0.065)\end{array}$ \\
\hline 4 years after MML & $\ldots$ & $\ldots$ & $\begin{array}{l}-0.138 * * * \\
(0.038)\end{array}$ & $\begin{array}{l}-0.108^{*} \\
(0.063)\end{array}$ & $\begin{array}{l}-0.112 * \\
(0.058)\end{array}$ \\
\hline 5+ years after MML & $\ldots$ & $\ldots$ & $\begin{array}{l}-0.102^{* * * *} \\
(0.026)\end{array}$ & $\begin{array}{l}-0.042 \\
(0.062)\end{array}$ & $\begin{array}{l}-0.047 \\
(0.059)\end{array}$ \\
\hline \multicolumn{3}{|c|}{ p-value: joint significance of lags } & $0.000 * * *$ & $0.089 *$ & $0.060 *$ \\
\hline $\mathrm{N}$ & 1071 & 1071 & 1071 & 1071 & 1071 \\
\hline $\mathrm{R}^{2}$ & 0.969 & 0.979 & 0.969 & 0.979 & 0.979 \\
\hline Year FEs & Yes & Yes & Yes & Yes & Yes \\
\hline State FEs & Yes & Yes & Yes & Yes & Yes \\
\hline State covariates & Yes & Yes & Yes & Yes & Yes \\
\hline State-specific trends & No & Yes & No & Yes & Yes \\
\hline
\end{tabular}

*Statistically significant at $10 \%$ level; **at $5 \%$ level; ***at $1 \%$ level.

Notes: Each column represents the results from a separate regression. The dependent variable is equal to the natural $\log$ of total fatalities per 100,000 population and the covariates are listed in Table 4. Regressions are weighted using state populations. Standard errors, corrected for clustering at the state level, are in parentheses. 
Table 6. Medical Marijuana Laws and Traffic Fatalities: The Role of Alcohol

\begin{tabular}{|c|c|c|c|c|c|c|}
\hline & $\begin{array}{c}\text { (1) } \\
\text { Fatalities } \\
\text { No Alcohol }\end{array}$ & $\begin{array}{c}\text { (2) } \\
\text { Fatalities } \\
\text { No Alcohol } \\
\end{array}$ & $\begin{array}{c}(3) \\
\text { Fatalities } \\
B A C>0\end{array}$ & $\begin{array}{l}(4) \\
\text { Fatalities } \\
B A C>0 \\
\end{array}$ & $\begin{array}{c}(5) \\
\text { Fatalities } \\
B A C \geq 0.10\end{array}$ & $\begin{array}{c}(6) \\
\text { Fatalities } \\
B A C \geq 0.10 \\
\end{array}$ \\
\hline MML & $\begin{array}{l}-0.075 \\
(0.062)\end{array}$ & $\ldots$ & $\begin{array}{l}-0.141 * \\
(0.077)\end{array}$ & $\ldots$ & $\begin{array}{l}-0.168 * * \\
(0.082)\end{array}$ & $\ldots$ \\
\hline Year of law change & $\ldots$ & $\begin{array}{l}-0.026 \\
(0.031)\end{array}$ & $\ldots$ & $\begin{array}{c}-0.011 \\
(0.040)\end{array}$ & $\ldots$ & $\begin{array}{l}-0.041 \\
(0.051)\end{array}$ \\
\hline 1 year after MML & $\ldots$ & $\begin{array}{l}-0.071 \\
(0.047)\end{array}$ & ... & $\begin{array}{l}-0.103 \\
(0.068)\end{array}$ & $\ldots$ & $\begin{array}{l}-0.124 \\
(0.086)\end{array}$ \\
\hline 2 years after MML & $\ldots$ & $\begin{array}{l}-0.085 \\
(0.079)\end{array}$ & $\ldots$ & $\begin{array}{l}-0.091 \\
(0.083)\end{array}$ & $\ldots$ & $\begin{array}{l}-0.117 \\
(0.081)\end{array}$ \\
\hline 3 years after MML & ... & $\begin{array}{l}-0.065 \\
(0.077)\end{array}$ & $\ldots$ & $\begin{array}{l}-0.237 * * * \\
(0.083)\end{array}$ & $\ldots$ & $\begin{array}{l}-0.292^{* * * *} \\
(0.100)\end{array}$ \\
\hline 4 years after MML & ... & $\begin{array}{l}-0.076 \\
(0.063)\end{array}$ & ... & $\begin{array}{l}-0.223 * * \\
(0.092)\end{array}$ & $\ldots$ & $\begin{array}{l}-0.256^{* * *} \\
(0.105)\end{array}$ \\
\hline 5+ years after MML & $\ldots$ & $\begin{array}{l}-0.024 \\
(0.062)\end{array}$ & $\ldots$ & $\begin{array}{l}-0.138 * \\
(0.081)\end{array}$ & $\ldots$ & $\begin{array}{l}-0.197 * * \\
(0.090)\end{array}$ \\
\hline p-value: joint significance of lags & & 0.244 & & $0.002 * * *$ & & $0.082 *$ \\
\hline $\begin{array}{l}\mathrm{N} \\
\mathrm{D}^{2}\end{array}$ & 1071 & 1071 & 1071 & 1071 & 1071 & 1071 \\
\hline $\mathrm{R}^{2}$ & 0.964 & 0.964 & 0.905 & 0.906 & 0.906 & 0.906 \\
\hline Year FE & Yes & Yes & Yes & Yes & Yes & Yes \\
\hline State FE & Yes & Yes & Yes & Yes & Yes & Yes \\
\hline Covariates & Yes & Yes & Yes & Yes & Yes & Yes \\
\hline State-specific trends & Yes & Yes & Yes & Yes & Yes & Yes \\
\hline
\end{tabular}

*Statistically significant at $10 \%$ level; **at $5 \%$ level; ***at $1 \%$ level.

Notes: Each column represents the results from a separate regression. The dependent variable is equal to the natural log of fatalities per 100,000 population and the covariates are listed in Table 4. Regressions are weighted using state populations. Standard errors, corrected for clustering at the state level, are in parentheses. 
Table 7. Medical Marijuana Laws and Traffic Fatalities by Day and Time

\begin{tabular}{lllll}
\hline & $\begin{array}{l}\text { Fatalities } \\
\text { weekdays }\end{array}$ & $\begin{array}{l}\text { Fatalities } \\
\text { weekend }\end{array}$ & $\begin{array}{l}\text { Fatalities } \\
\text { daytime }\end{array}$ & $\begin{array}{l}\text { Fatalities } \\
\text { nighttime }\end{array}$ \\
\hline MML & -0.083 & $-0.115^{*}$ & -0.076 & $-0.117^{*}$ \\
& $(0.069)$ & $(0.061)$ & $(0.066)$ & $(0.069)$ \\
$\mathrm{N}$ & 1071 & 1071 & 1071 & 1071 \\
$\mathrm{R}^{2}$ & 0.970 & 0.961 & 0.968 & 0.966 \\
& & & & \\
Year FE & Yes & Yes & Yes & Yes \\
State FE & Yes & Yes & Yes & Yes \\
Covariates & Yes & Yes & Yes & Yes \\
State-specific trends & Yes & Yes & Yes & Yes \\
\hline
\end{tabular}

*Statistically significant at $10 \%$ level; **at $5 \%$ level; ***at $1 \%$ level.

Notes: Each column represents the results from a separate regression. The dependent variable is equal to the natural $\log$ of fatalities per 100,000 population and the covariates are listed in Table 4. Regressions are weighted using state populations. Standard errors, corrected for clustering at the state level, are in parentheses. 
Table 8. Medical Marijuana Laws and Traffic Fatalities by Age

Fatalities 15-19 Fatalities 20-29 Fatalities 30-39 Fatalities 40-49 Fatalities 50-59 Fatalities 60+

\begin{tabular}{|c|c|c|c|c|c|c|}
\hline MML & $\begin{array}{l}-0.022 \\
(0.083)\end{array}$ & $\begin{array}{l}-0.183^{*} * \\
(0.073)\end{array}$ & $\begin{array}{l}-0.175^{*} \\
(0.096)\end{array}$ & $\begin{array}{l}-0.094 \\
(0.070)\end{array}$ & $\begin{array}{l}-0.038 \\
(0.056)\end{array}$ & $\begin{array}{c}-0.048 \\
(0.048)\end{array}$ \\
\hline $\begin{array}{l}\mathrm{N} \\
\mathrm{R}^{2}\end{array}$ & $\begin{array}{l}1071 \\
0.915\end{array}$ & $\begin{array}{l}1071 \\
0.940\end{array}$ & $\begin{array}{l}1071 \\
0.943\end{array}$ & $\begin{array}{l}1071 \\
0.939\end{array}$ & $\begin{array}{l}1071 \\
0.874\end{array}$ & $\begin{array}{l}1071 \\
0.921\end{array}$ \\
\hline $\begin{array}{l}\text { Year FE } \\
\text { State FE } \\
\text { Covariates } \\
\text { State-specific trends }\end{array}$ & $\begin{array}{l}\text { Yes } \\
\text { Yes } \\
\text { Yes } \\
\text { Yes }\end{array}$ & $\begin{array}{l}\text { Yes } \\
\text { Yes } \\
\text { Yes } \\
\text { Yes }\end{array}$ & $\begin{array}{l}\text { Yes } \\
\text { Yes } \\
\text { Yes } \\
\text { Yes }\end{array}$ & $\begin{array}{l}\text { Yes } \\
\text { Yes } \\
\text { Yes } \\
\text { Yes }\end{array}$ & $\begin{array}{l}\text { Yes } \\
\text { Yes } \\
\text { Yes } \\
\text { Yes }\end{array}$ & $\begin{array}{l}\text { Yes } \\
\text { Yes } \\
\text { Yes } \\
\text { Yes }\end{array}$ \\
\hline
\end{tabular}

*Statistically significant at $10 \%$ level; **at $5 \%$ level; ***at $1 \%$ level.

Notes: Each column represents the results from a separate regression. The dependent variable is equal to the natural log of fatalities per 100,000 population and the covariates are listed in Table 4. Regressions are weighted using the relevant state-by-age populations. Standard errors, corrected for clustering at the state level, are in parentheses. 


\section{Fatalities males $\quad$ Fatalities females}

\begin{tabular}{lcc} 
MML & $-0.114^{*}$ & -0.072 \\
& $(0.065)$ & $(0.073)$ \\
$\mathrm{N}$ & 1071 & 1071 \\
$\mathrm{R}^{2}$ & 0.974 & 0.960 \\
& & \\
Year FE & Yes & Yes \\
State FE & Yes & Yes \\
Covariates & Yes & Yes \\
State-specific trends & Yes & Yes \\
\hline
\end{tabular}

*Statistically significant at $10 \%$ level; **at $5 \%$ level; ***at $1 \%$ level.

Notes: Each column represents the results from a separate regression. The dependent variable is equal to the natural $\log$ of fatalities per 100,000 population and the covariates are listed in Table 4. Regressions are weighted using the relevant state-by-sex populations. Standard errors, corrected for clustering at the state level, are in parentheses. 
Table 10. Tests of Endogeneity

\begin{tabular}{|c|c|c|c|c|c|c|c|}
\hline & & acebo MMI & & \multirow{2}{*}{$\begin{array}{c}\text { Falsification } \\
\text { Test } \\
\\
\text { Fatalities } \\
\text { Tire or Wheel } \\
\text { Failure a Factor }\end{array}$} & \multicolumn{3}{|c|}{ Spending on Enforcement and Highway Services } \\
\hline & $\begin{array}{c}\text { Fatalities } \\
\text { Total } \\
\end{array}$ & $\begin{array}{l}\text { Fatalities } \\
B A C>0\end{array}$ & $\begin{array}{c}\text { Fatalities } \\
B A C \geq 0.10\end{array}$ & & $\begin{array}{c}\text { Police } \\
\text { Expenditures } \\
\end{array}$ & $\begin{array}{l}\text { Highway Law } \\
\text { Enforcement } \\
\text { Expenditures }\end{array}$ & $\begin{array}{c}\text { Highway } \\
\text { Maintenance } \\
\text { Expenditures } \\
\end{array}$ \\
\hline Average Placebo $M M L$ estimate & 0.003 & 0.011 & 0.012 & $\cdots$ & $\cdots$ & $\cdots$ & $\cdots$ \\
\hline MML & $\ldots$ & $\cdots$ & $\ldots$ & $\begin{array}{c}0.018 \\
(0.147)\end{array}$ & $\begin{array}{l}-0.009 \\
(0.020)\end{array}$ & $\begin{array}{l}-0.004 \\
(0.051)\end{array}$ & $\begin{array}{l}-0.092 \\
(0.068)\end{array}$ \\
\hline $\mathrm{N}$ & 1071 & 1071 & 1071 & 1020 & 919 & 1050 & 1050 \\
\hline Number of trials & 100 & 100 & 100 & $\cdots$ & $\cdots$ & $\ldots$ & $\cdots$ \\
\hline Placebo Coefficient $<0$ & 42 & 44 & 42 & $\cdots$ & $\ldots$ & $\cdots$ & $\cdots$ \\
\hline $\begin{array}{l}\text { Placebo Coefficient }<0 \\
\text { and sig. at } 5 \% \text { level }\end{array}$ & 2 & 3 & 3 & $\ldots$ & $\ldots$ & $\cdots$ & $\cdots$ \\
\hline $\begin{array}{l}\text { Placebo Coefficient }<0 \\
\text { and sig. at } 10 \% \text { level }\end{array}$ & 2 & 4 & 4 & & & & \\
\hline Year FE & Yes & Yes & Yes & Yes & Yes & Yes & Yes \\
\hline State FE & Yes & Yes & Yes & Yes & Yes & Yes & Yes \\
\hline Covariates & Yes & Yes & Yes & Yes & Yes & Yes & Yes \\
\hline$\underline{\text { State-specific trends }}$ & Yes & Yes & Yes & Yes & Yes & Yes & Yes \\
\hline
\end{tabular}

*Statistically significant at $10 \%$ level; **at $5 \%$ level; ***at $1 \%$ level.

Notes: The first three columns represent the results from a series of regressions in which the dependent variable is equal to the natural log of fatalities per 100,000 population and the covariates are listed in Table 4. Regressions are weighted using state populations and standard errors are corrected for clustering at the state level. In the fourth column, the dependent variable is equal to the natural log of fatalities per 100,000 population from crashes in which tire or wheel failure was cited as a potential contributing factor to the accident. Covariates are listed in Table 4, the regression is weighted using state populations, and the standard error, corrected for clustering at the state-level, is in parentheses. The remaining columns represent the results from separate regressions in which the dependent variable is equal to the natural log of the indicated spending measure. The covariates are the state unemployment rate and income per capita. Regressions are weighted using state populations, and standard errors, corrected for clustering at the state level, are in parentheses. 
Table 11. Medical Marijuana Laws and State-Level Covariates

\begin{tabular}{|c|c|c|c|c|}
\hline & $\begin{array}{c}(1) \\
M M L \\
\end{array}$ & $\begin{array}{c}(2) \\
M M L \\
\end{array}$ & $\begin{array}{c}(3) \\
M M L \\
\end{array}$ & $\begin{array}{c}(4) \\
M M L\end{array}$ \\
\hline Mean age & $\begin{array}{c}0.035 \\
(0.131)\end{array}$ & $\begin{array}{c}0.035 \\
(0.148)\end{array}$ & $\begin{array}{c}0.041 \\
(0.152)\end{array}$ & $\begin{array}{c}0.037 \\
(0.139)\end{array}$ \\
\hline Unemployment & $\begin{array}{l}-0.011 \\
(0.037)\end{array}$ & $\begin{array}{l}-0.015 \\
(0.039)\end{array}$ & $\begin{array}{l}-0.014 \\
(0.039)\end{array}$ & $\begin{array}{c}0.007 \\
(0.027)\end{array}$ \\
\hline Income & $\begin{array}{c}0.231 \\
(0.362)\end{array}$ & $\begin{array}{c}0.187 \\
(0.359)\end{array}$ & $\begin{array}{c}0.241 \\
(0.348)\end{array}$ & $\begin{array}{c}0.255 \\
(0.363)\end{array}$ \\
\hline Miles driven & $\begin{array}{c}0.004 \\
(0.008)\end{array}$ & $\begin{array}{c}0.006 \\
(0.009)\end{array}$ & $\begin{array}{c}0.005 \\
(0.009)\end{array}$ & $\begin{array}{c}0.015 \\
(0.013)\end{array}$ \\
\hline BAC 0.08 & $\ldots$ & $\begin{array}{l}0.062 \\
(0.047)\end{array}$ & $\begin{array}{c}0.052 \\
(0.045)\end{array}$ & $\begin{array}{c}0.061 \\
(0.048)\end{array}$ \\
\hline ALR & $\ldots$ & $\begin{array}{l}-0.034 \\
(0.063)\end{array}$ & $\begin{array}{l}-0.027 \\
(0.061)\end{array}$ & $\begin{array}{l}-0.027 \\
(0.069)\end{array}$ \\
\hline Zero Tolerance & $\ldots$ & $\begin{array}{l}-0.091 \\
(0.066)\end{array}$ & $\begin{array}{l}-0.090 \\
(0.065)\end{array}$ & $\begin{array}{l}-0.075 \\
(0.053)\end{array}$ \\
\hline Beer tax & $\ldots$ & $\begin{array}{c}0.375 \\
(0.643)\end{array}$ & $\begin{array}{c}0.364 \\
(0.636)\end{array}$ & $\begin{array}{c}0.119 \\
(0.286)\end{array}$ \\
\hline Decriminalized & $\ldots$ & $\ldots$ & $\begin{array}{c}0.212 \\
(0.245)\end{array}$ & $\begin{array}{c}0.180 \\
(0.282)\end{array}$ \\
\hline Drug per se & $\ldots$ & $\ldots$ & $\begin{array}{c}0.035 \\
(0.049)\end{array}$ & $\begin{array}{c}0.015 \\
(0.039)\end{array}$ \\
\hline GDL & $\ldots$ & $\ldots$ & $\ldots$ & $\begin{array}{c}0.035 \\
(0.031)\end{array}$ \\
\hline Primary seatbelt & $\ldots$ & $\ldots$ & $\ldots$ & $\begin{array}{c}0.010 \\
(0.057)\end{array}$ \\
\hline Secondary seatbelt & $\ldots$ & $\ldots$ & $\ldots$ & $\begin{array}{c}0.020 \\
(0.040)\end{array}$ \\
\hline Speed 70 & $\ldots$ & $\ldots$ & $\ldots$ & $\begin{array}{c}0.060 \\
(0.066)\end{array}$ \\
\hline Texting ban & .. & $\ldots$ & $\ldots$ & $\begin{array}{c}0.013 \\
(0.049)\end{array}$ \\
\hline Hands Free & $\ldots$ & $\ldots$ & $\ldots$ & $\begin{array}{c}-0.348 * * \\
(0.164)\end{array}$ \\
\hline $\begin{array}{l}\mathrm{N} \\
\mathrm{R}^{2}\end{array}$ & $\begin{array}{l}1071 \\
0.869\end{array}$ & $\begin{array}{l}1071 \\
0.873\end{array}$ & $\begin{array}{l}1071 \\
0.874\end{array}$ & $\begin{array}{l}1071 \\
0.884\end{array}$ \\
\hline State-level characteristics & Yes & Yes & Yes & Yes \\
\hline Alcohol policies & No & Yes & Yes & Yes \\
\hline Drug policies & No & No & Yes & Yes \\
\hline Other traffic policies & No & No & No & Yes \\
\hline Year FE & Yes & Yes & Yes & Yes \\
\hline State FE & Yes & Yes & Yes & Yes \\
\hline State-specific trends & Yes & Yes & Yes & Yes \\
\hline
\end{tabular}

*Statistically significant at $10 \%$ level; **at $5 \%$ level; ***at $1 \%$ level.

Notes: Each column represents the results from a separate regression. Regressions are weighted using state populations. Standard errors, corrected for clustering at the state level, are in parentheses. 
Table 12. Medical Marijuana Laws and Alcohol Consumption in the Past 30 Days: Evidence from the BRFSS

\begin{tabular}{|c|c|c|c|c|c|c|c|}
\hline & $\begin{array}{c}\text { All } \\
\text { respondents }\end{array}$ & $\begin{array}{c}18-19 \\
\text { years of age }\end{array}$ & $\begin{array}{c}20-29 \\
\text { years of age }\end{array}$ & $\begin{array}{c}30-39 \\
\text { years of age }\end{array}$ & $\begin{array}{c}40-49 \\
\text { years of age }\end{array}$ & $\begin{array}{c}50-59 \\
\text { years of age }\end{array}$ & $\begin{array}{c}60+ \\
\text { years of age } \\
\end{array}$ \\
\hline Drank $>0$ & $\begin{array}{c}-0.019 * \\
(0.010) \\
{[3884082]}\end{array}$ & $\begin{array}{l}-0.051 * * \\
(0.020) \\
{[54296]}\end{array}$ & $\begin{array}{c}-0.031 * \\
(0.017) \\
{[378058]}\end{array}$ & $\begin{array}{c}-0.022 \\
(0.014) \\
{[614541]}\end{array}$ & $\begin{array}{c}-0.017 \\
(0.012) \\
{[739094]}\end{array}$ & $\begin{array}{c}-0.016 * \\
(0.009) \\
{[760147]}\end{array}$ & $\begin{array}{c}-0.012 \\
(0.008) \\
{[1337946]}\end{array}$ \\
\hline $15+$ Drinks & $\begin{array}{c}-0.010 * \\
(0.006) \\
{[3884082]}\end{array}$ & $\begin{array}{c}-0.022 * \\
(0.011) \\
{[54296]}\end{array}$ & $\begin{array}{c}-0.015 \\
(0.011) \\
{[378058]}\end{array}$ & $\begin{array}{c}-0.015 * * \\
(0.008) \\
{[614541]}\end{array}$ & $\begin{array}{c}-0.009 \\
(0.006) \\
{[739094]}\end{array}$ & $\begin{array}{c}-0.014 * * \\
(0.005) \\
{[760147]}\end{array}$ & $\begin{array}{c}-0.004 \\
(0.005) \\
{[1337946]}\end{array}$ \\
\hline $30+$ Drinks & $\begin{array}{c}-0.009 * \\
(0.005) \\
{[3884082]}\end{array}$ & $\begin{array}{c}-0.017 * * \\
(0.008) \\
{[54296]}\end{array}$ & $\begin{array}{c}-0.018 * \\
(0.009) \\
{[378058]}\end{array}$ & $\begin{array}{c}-0.008 \\
(0.007) \\
{[614541]}\end{array}$ & $\begin{array}{c}-0.010^{*} \\
(0.006) \\
{[739094]}\end{array}$ & $\begin{array}{c}-0.009 * * \\
(0.004) \\
{[760147]}\end{array}$ & $\begin{array}{c}-0.003 \\
(0.004) \\
{[1337946]}\end{array}$ \\
\hline $60+$ Drinks & $\begin{array}{c}-0.004 \\
(0.003) \\
{[3884082]}\end{array}$ & $\begin{array}{c}-0.008 \\
(0.007) \\
{[54296]}\end{array}$ & $\begin{array}{c}-0.011 * * \\
(0.005) \\
{[378058]}\end{array}$ & $\begin{array}{c}-0.003 \\
(0.005) \\
{[614541]}\end{array}$ & $\begin{array}{c}-0.005 \\
(0.003) \\
{[739094]}\end{array}$ & $\begin{array}{c}-0.003 \\
(0.003) \\
{[760147]}\end{array}$ & $\begin{array}{c}-0.002 \\
(0.002) \\
{[1337946]}\end{array}$ \\
\hline Binge Drank & $\begin{array}{c}-0.007 * \\
(0.003) \\
{[3928524]}\end{array}$ & $\begin{array}{c}-0.018 * \\
(0.009) \\
{[55426]}\end{array}$ & $\begin{array}{c}-0.012 \\
(0.010) \\
{[383970]}\end{array}$ & $\begin{array}{c}-0.007 \\
(0.006) \\
{[621722]}\end{array}$ & $\begin{array}{c}-0.013 * * \\
(0.005) \\
{[746974]}\end{array}$ & $\begin{array}{c}-0.007 * \\
(0.004) \\
{[767567]}\end{array}$ & $\begin{array}{c}-0.002 \\
(0.002) \\
{[1352865]}\end{array}$ \\
\hline $2+$ Binges & $\begin{array}{c}-0.004 * \\
(0.002) \\
{[3928524]}\end{array}$ & $\begin{array}{c}-0.010 \\
(0.011) \\
{[55426]}\end{array}$ & $\begin{array}{c}-0.012 * \\
(0.007) \\
{[383970]}\end{array}$ & $\begin{array}{c}-0.002 \\
(0.004) \\
{[621722]}\end{array}$ & $\begin{array}{c}-0.006^{*} \\
(0.003) \\
{[746974]}\end{array}$ & $\begin{array}{c}-0.005 \\
(0.003) \\
{[767567]}\end{array}$ & $\begin{array}{c}-0.001 \\
(0.002) \\
{[1352865]}\end{array}$ \\
\hline $\begin{array}{l}\text { Number of drinks } \\
\text { conditional on } \\
\text { drinking }\end{array}$ & $\begin{array}{c}-0.84 \\
(0.66) \\
{[1900760]}\end{array}$ & $\begin{array}{c}-1.38 \\
(1.83) \\
{[19944]}\end{array}$ & $\begin{array}{l}-2.40 * * \\
(0.97) \\
{[222500]}\end{array}$ & $\begin{array}{c}-0.70 \\
(0.95) \\
{[350855]}\end{array}$ & $\begin{array}{c}-0.66 \\
(0.57) \\
{[414093]}\end{array}$ & $\begin{array}{c}-0.93 \\
(0.57) \\
{[386371]}\end{array}$ & $\begin{array}{c}-0.44 \\
(0.75) \\
{[506997]}\end{array}$ \\
\hline
\end{tabular}

*Statistically significant at $10 \%$ level; **at $5 \%$ level; ***at $1 \%$ level.

Notes: Based on information collected from the Behavioral Risk Factor Surveillance System (BRFSS) for the period 1993-2010. Each cell represents the results from a separate regression. The covariates include indicators for race, ethnicity, sex, marital status, employment status and educational attainment, state fixed effects, year fixed effects, state-specific linear time trends, the unemployment rate, per capita income, the state beer tax, and indicators for marijuana decriminalization, BAC 0.08 and Zero Tolerance. Indicators for age group are included when using all BRFSS respondents. Standard errors, corrected for clustering at the state level, are in parentheses. Sample sizes are in brackets. 
Table 13. Per-Capita Alcohol Sales, Medical Marijuana Laws and Traffic Fatalities

First-stage regressions

$\ln ($ beer sales $)$

ln(wine sales)

$\ln ($ spirits sales $)$

$\begin{array}{lccc}\text { MML } & -0.049^{* *} & -0.008 & 0.002 \\ & (0.022) & (0.013) & (0.011) \\ \mathrm{N} & 1071 & 867 & 867 \\ \mathrm{R}^{2} & 0.981 & 0.990 & 0.990 \\ \text { F-test on instrument } & 4.8 & 0.36 & 0.03\end{array}$

Second-stage regressions

\begin{tabular}{lccc} 
& $\begin{array}{c}\text { Fatalities } \\
\text { Total }\end{array}$ & $\begin{array}{c}\text { Fatalities } \\
\text { BAC }>0\end{array}$ & Fatalities \\
Ln(beer sales) & & & \\
& $1.68^{* * *}$ & $2.40^{* * *}$ & 0.10 \\
& $(0.484)$ & $(0.764)$ & $3.16^{* * * *}$ \\
$\mathrm{~N}$ & 1071 & & $(0.841)$ \\
$\mathrm{R}^{2}$ & 0.976 & 1071 & 1071 \\
& & 0.900 & 0.897 \\
Year FE & Yes & & \\
State FE & Yes & Yes & Yes \\
Covariates & Yes & Yes & Yes \\
State-specific trends & Yes & Yes & Yes \\
\hline
\end{tabular}

*Statistically significant at $10 \%$ level; **at $5 \%$ level; ***at $1 \%$ level.

Notes: The dependent variable in the first-stage regressions is equal to the natural log of per-capita sales in state $s$ and year $t$ (measured in gallons) and is based on data from the Brewers Almanac. Beer sales data are for the period 1990-2010. Wine and spirits sales data are for the period 1994-2010. The dependent variable in the second-stage regressions is equal to the natural $\log$ of traffic fatalities per 100,000 population. Controls include the state unemployment rate, per capita income, the state beer tax, and indicators for marijuana decriminalization, BAC 0.08 , administrative license revocation, and Zero Tolerance. Regressions are weighted using state populations. Standard errors, corrected for clustering at the state level, are in parentheses. 
Appendix Table 1. Available Registry Information by State, 2011

\begin{tabular}{llllll}
\hline & $\begin{array}{l}\text { Number of } \\
\text { registered } \\
\text { patients }\end{array}$ & $\begin{array}{l}\text { Chronic } \\
\text { pain }(\%)\end{array}$ & Male (\%) & $\begin{array}{c}\text { Average } \\
\text { age }\end{array}$ & $\begin{array}{c}\text { 18-40 years } \\
\text { of age (\%) }\end{array}$ \\
\hline Alaska & $380^{\mathrm{a}}$ & $\ldots$ & $\ldots$ & $\ldots$ & $\ldots$ \\
Arizona & 11,133 & 86 & 75 & $\ldots$ & 42 \\
California & $1,250,000^{\mathrm{b}}$ & $\ldots$ & $\ldots$ & $\ldots$ & $\ldots$ \\
Colorado & 128,698 & 94 & 69 & 40 & $\ldots$ \\
Hawaii & $8,000^{\mathrm{c}}$ & $\ldots$ & $\ldots$ & $\ldots$ & $\ldots$ \\
Maine & 796 & $\ldots$ & $\ldots$ & $\ldots$ & $\ldots$ \\
Michigan & 105,458 & $\ldots$ & $\ldots$ & $\ldots$ & $\ldots$ \\
Montana & 30,036 & 86 & $\ldots$ & $\ldots$ & $\ldots$ \\
New Mexico & 3,981 & 24 & $\ldots$ & $\ldots$ & $\ldots$ \\
Oregon & 49,220 & 65 & $\ldots$ & $\ldots$ & $\ldots$ \\
Rhode Island & 3,073 & 20 & $\ldots$ & $\ldots$ & $\ldots$ \\
Vermont & $349^{\mathrm{d}}$ & & $\ldots$ & $\ldots$ & $\ldots$ \\
\hline
\end{tabular}

${ }^{a}$ Based on a communication between NORML and the Alaska Bureau of Vital Statistics.

${ }^{\mathrm{b}}$ Estimated by NORML.

${ }^{\mathrm{c}}$ Estimated by the Drug Policy Forum of Hawaii.

${ }^{\mathrm{d}}$ Based on a communication between NORML and the Vermont Criminal Information Center.

${ }^{\mathrm{e}}$ Estimated by NORML.

Notes: Unless otherwise indicated, the information in this table was obtained from official state registry data. Links to state registry data are available at: http://norml.org/index.cfm?Group_ID=3391 
Appendix Table 2. Summary of Medical Marijuana Laws by State

\begin{tabular}{|c|c|c|c|}
\hline \multicolumn{2}{|c|}{$\begin{array}{l}\text { Caregivers can have multiple patients or collective growing by } \\
\text { patients is allowed }\end{array}$} & \multicolumn{2}{|c|}{$\begin{array}{l}\text { Caregivers limited to one patient or collective growing by } \\
\text { caregivers is prohibited }\end{array}$} \\
\hline California & $\begin{array}{l}\text { Caregivers can have multiple patients. Home } \\
\text { cultivation and collectives/cooperatives allowed. }\end{array}$ & Alaska & $\begin{array}{l}\text { Caregivers limited to one patient (unless a } \\
\text { relative of more than one patient). Home } \\
\text { cultivation allowed but dispensaries prohibited. }\end{array}$ \\
\hline Colorado & $\begin{array}{l}\text { Caregivers can have multiple patients. Home } \\
\text { cultivation and dispensaries allowed. }\end{array}$ & $\begin{array}{l}\text { District of } \\
\text { Columbia }\end{array}$ & $\begin{array}{l}\text { Caregivers limited to one patient. Home } \\
\text { cultivation prohibited. Five licensed } \\
\text { dispensaries and } 10 \text { cultivation facilities. }\end{array}$ \\
\hline Michigan and Montana & $\begin{array}{l}\text { Caregivers can have multiple patients. Home } \\
\text { cultivation allowed. }\end{array}$ & Hawaii & $\begin{array}{l}\text { Caregivers limited to one patient. Home } \\
\text { cultivation allowed but dispensaries prohibited. }\end{array}$ \\
\hline Nevada & $\begin{array}{l}\text { Caregivers can have multiple patients. } \\
\text { Home cultivation allowed. Dispensaries are } \\
\text { prohibited. }\end{array}$ & Maine & $\begin{array}{l}\text { Caregivers can have multiple patients but are } \\
\text { prohibited from cultivating collectively. Home } \\
\text { cultivation and a limited number of licensed, } \\
\text { non-profit dispensaries are allowed. }\end{array}$ \\
\hline Oregon & $\begin{array}{l}\text { Caregivers can have multiple patients. Home } \\
\text { cultivation for multiple patients allowed. } \\
\text { Dispensaries are prohibited but collectives/ } \\
\text { cooperatives are allowed. }\end{array}$ & New Jersey & $\begin{array}{l}\text { Caregivers limited to one patient. Home } \\
\text { cultivation prohibited. Ten licensed nonprofit } \\
\text { dispensaries/cultivation centers. }\end{array}$ \\
\hline Rhode Island & $\begin{array}{l}\text { Caregivers can have multiple patients. Home } \\
\text { cultivation and up to } 3 \text { licensed, non-profit } \\
\text { compassion centers allowed. }\end{array}$ & New Mexico & $\begin{array}{l}\text { Caregivers can have multiple patients but are } \\
\text { prohibited from cultivating. Home cultivation } \\
\text { allowed with license. Limited number of } \\
\text { licensed, non-profit producers. }\end{array}$ \\
\hline Washington & $\begin{array}{l}\text { Caregivers limited to one patient, but home } \\
\text { cultivation and collective cultivation by patients } \\
\text { allowed. }\end{array}$ & Vermont & $\begin{array}{l}\text { Caregivers limited to one patient. Home } \\
\text { cultivation allowed. Four licensed, nonprofit } \\
\text { dispensaries. }\end{array}$ \\
\hline
\end{tabular}

Notes: Based on information from the Marijuana Policy Project (www.mpp.org) and Jacobson et al. (2011). 


\begin{tabular}{|c|c|c|}
\hline Dependent Variable & Mean (SD) & Description \\
\hline $\begin{array}{l}\text { Price High-Quality } \\
\text { Marijuana }\end{array}$ & $313.25(88.13)$ & $\begin{array}{l}\text { Median per-ounce price of high quality marijuana } \\
\text { (2000 dollars) }\end{array}$ \\
\hline $\begin{array}{l}\text { Price Low-Quality } \\
\text { Marijuana }\end{array}$ & $128.70(64.24)$ & $\begin{array}{l}\text { Median per-ounce price of low quality marijuana } \\
\text { (2000 dollars) }\end{array}$ \\
\hline Independent Variable & Mean (SD) & Description \\
\hline$M M L^{a}$ & $0.135(0.338)$ & $\begin{array}{l}=1 \text { if a state had a medical marijuana law in a given } \\
\text { year, }=0 \text { otherwise }\end{array}$ \\
\hline Mean age & $36.08(1.78)$ & Mean age of the state population \\
\hline Unemployment & $5.70(1.92)$ & State unemployment rate \\
\hline Income & $10.25(0.173)$ & $\begin{array}{l}\text { Natural logarithm of state real income per capita } \\
\text { (2000 dollars) }\end{array}$ \\
\hline Decriminalized $^{a}$ & $0.250(0.433)$ & $\begin{array}{l}=1 \text { if a state had a marijuana decriminalization law } \\
\text { in a given year, }=0 \text { otherwise }\end{array}$ \\
\hline Beer tax & $0.259(0.230)$ & Real beer tax (2000 dollars) \\
\hline
\end{tabular}

${ }^{a}$ Takes on fractional values for the years in which laws changed.

Note: Price data are based on information from 8,271 purchases recorded in the Trans High Market Quotations section of High Times. Of these, 7,029 were classified as high-quality and 1,242 were classified as low-quality. 
Appendix Table 4A. Traffic Fatalities and Medical Marijuana Laws by Age and Gender (Males)

\begin{tabular}{|c|c|c|c|c|c|c|}
\hline & Fatalities 15-19 & Fatalities 20-29 & Fatalities 30-39 & Fatalities 40-49 & Fatalities 50-59 & Fatalities $60_{+}$ \\
\hline MML & $\begin{array}{l}-0.071 \\
(0.067)\end{array}$ & $\begin{array}{l}-0.189 * * \\
(0.080)\end{array}$ & $\begin{array}{l}-0.158 * \\
(0.089)\end{array}$ & $\begin{array}{l}-0.095 \\
(0.074)\end{array}$ & $\begin{array}{l}-0.040 \\
(0.059)\end{array}$ & $\begin{array}{l}-0.087 * \\
(0.046)\end{array}$ \\
\hline $\begin{array}{l}\mathrm{N} \\
\mathrm{R}^{2}\end{array}$ & $\begin{array}{l}1071 \\
0.884\end{array}$ & $\begin{array}{l}1071 \\
0.924\end{array}$ & $\begin{array}{l}1071 \\
0.920\end{array}$ & $\begin{array}{l}1071 \\
0.909\end{array}$ & $\begin{array}{l}1071 \\
0.842\end{array}$ & $\begin{array}{l}1071 \\
0.892\end{array}$ \\
\hline $\begin{array}{l}\text { Year FE } \\
\text { State FE } \\
\text { Covariates } \\
\text { State-specific trends }\end{array}$ & $\begin{array}{l}\text { Yes } \\
\text { Yes } \\
\text { Yes } \\
\text { Yes }\end{array}$ & $\begin{array}{l}\text { Yes } \\
\text { Yes } \\
\text { Yes } \\
\text { Yes }\end{array}$ & $\begin{array}{l}\text { Yes } \\
\text { Yes } \\
\text { Yes } \\
\text { Yes }\end{array}$ & $\begin{array}{l}\text { Yes } \\
\text { Yes } \\
\text { Yes } \\
\text { Yes }\end{array}$ & $\begin{array}{l}\text { Yes } \\
\text { Yes } \\
\text { Yes } \\
\text { Yes }\end{array}$ & $\begin{array}{l}\text { Yes } \\
\text { Yes } \\
\text { Yes } \\
\text { Yes }\end{array}$ \\
\hline
\end{tabular}

*Statistically significant at $10 \%$ level; **at $5 \%$ level; ***at $1 \%$ level.

Notes: Each column represents the results from a separate regression. The dependent variable is equal to the natural log of fatalities per 100,000 population and the covariates are listed in Table 4. Regressions are weighted using the relevant state-by-age populations. Standard errors, corrected for clustering at the state level, are in parentheses. 
Appendix Table 4B. Medical Marijuana Laws and Traffic Fatalities by Age and Gender (Females)

\begin{tabular}{|c|c|c|c|c|c|c|}
\hline & Fatalities 15-19 & Fatalities 20-29 & Fatalities 30-39 & Fatalities 40-49 & Fatalities 50-59 & Fatalities $60+$ \\
\hline MML & $\begin{array}{c}0.037 \\
(0.123)\end{array}$ & $\begin{array}{l}-0.159 * * * \\
(0.058)\end{array}$ & $\begin{array}{l}-0.221 * \\
(0.127)\end{array}$ & $\begin{array}{l}-0.076 \\
(0.080)\end{array}$ & $\begin{array}{l}-0.040 \\
(0.079)\end{array}$ & $\begin{array}{c}0.019 \\
(0.059)\end{array}$ \\
\hline $\begin{array}{l}\mathrm{N} \\
\mathrm{R}^{2}\end{array}$ & $\begin{array}{l}1071 \\
0.789\end{array}$ & $\begin{array}{l}1071 \\
0.861\end{array}$ & $\begin{array}{l}1071 \\
0.833\end{array}$ & $\begin{array}{l}1071 \\
0.824\end{array}$ & $\begin{array}{l}1071 \\
0.703\end{array}$ & $\begin{array}{l}1071 \\
0.838\end{array}$ \\
\hline $\begin{array}{l}\text { Year FE } \\
\text { State FE } \\
\text { Covariates } \\
\text { State-specific trends }\end{array}$ & $\begin{array}{l}\text { Yes } \\
\text { Yes } \\
\text { Yes } \\
\text { Yes }\end{array}$ & $\begin{array}{l}\text { Yes } \\
\text { Yes } \\
\text { Yes } \\
\text { Yes }\end{array}$ & $\begin{array}{l}\text { Yes } \\
\text { Yes } \\
\text { Yes } \\
\text { Yes }\end{array}$ & $\begin{array}{l}\text { Yes } \\
\text { Yes } \\
\text { Yes } \\
\text { Yes }\end{array}$ & $\begin{array}{l}\text { Yes } \\
\text { Yes } \\
\text { Yes } \\
\text { Yes }\end{array}$ & $\begin{array}{l}\text { Yes } \\
\text { Yes } \\
\text { Yes } \\
\text { Yes }\end{array}$ \\
\hline
\end{tabular}

*Statistically significant at $10 \%$ level; **at $5 \%$ level; ***at $1 \%$ level.

Notes: Each column represents the results from a separate regression. The dependent variable is equal to the natural log of fatalities per 100,000 population and the covariates are listed in Table 4. Regressions are weighted using the relevant state-by-age populations. Standard errors, corrected for clustering at the state level, are in parentheses. 
Appendix Table 5. Alcohol Consumption in the Past 30 Days: Variable Means

\begin{tabular}{|c|c|c|c|c|c|c|c|}
\hline & $\begin{array}{l}\text { All BRFSS } \\
\text { respondents }\end{array}$ & $\begin{array}{c}18-19 \\
\text { years of age }\end{array}$ & $\begin{array}{c}20-29 \\
\text { years of age }\end{array}$ & $\begin{array}{c}30-39 \\
\text { years of age }\end{array}$ & $\begin{array}{c}40-49 \\
\text { years of age }\end{array}$ & $\begin{array}{c}50-59 \\
\text { years of age }\end{array}$ & $\begin{array}{c}60+ \\
\text { years of age }\end{array}$ \\
\hline Drank $>0$ & $\begin{array}{c}0.489 \\
{[3884082]}\end{array}$ & $\begin{array}{c}0.367 \\
{[54296]}\end{array}$ & $\begin{array}{c}0.589 \\
{[378058]}\end{array}$ & $\begin{array}{c}0.571 \\
{[614541]}\end{array}$ & $\begin{array}{c}0.560 \\
{[739094]}\end{array}$ & $\begin{array}{c}0.508 \\
{[760147]}\end{array}$ & $\begin{array}{c}0.379 \\
{[1337946]}\end{array}$ \\
\hline $15+$ Drinks & $\begin{array}{c}0.188 \\
{[3884082]}\end{array}$ & $\begin{array}{c}0.147 \\
{[54296]}\end{array}$ & $\begin{array}{c}0.237 \\
{[378058]}\end{array}$ & $\begin{array}{c}0.200 \\
{[614541]}\end{array}$ & $\begin{array}{c}0.210 \\
{[739094]}\end{array}$ & $\begin{array}{c}0.196 \\
{[760147]}\end{array}$ & $\begin{array}{c}0.154 \\
{[1337946]}\end{array}$ \\
\hline $30+$ Drinks & $\begin{array}{c}0.106 \\
{[3884082]}\end{array}$ & $\begin{array}{c}0.091 \\
{[54296]}\end{array}$ & $\begin{array}{c}0.129 \\
{[378058]}\end{array}$ & $\begin{array}{c}0.100 \\
{[614541]}\end{array}$ & $\begin{array}{c}0.110 \\
{[739094]}\end{array}$ & $\begin{array}{c}0.111 \\
{[760147]}\end{array}$ & $\begin{array}{c}0.097 \\
{[1337946]}\end{array}$ \\
\hline $60+$ Drinks & $\begin{array}{c}0.044 \\
{[3884082]}\end{array}$ & $\begin{array}{c}0.047 \\
{[54296]}\end{array}$ & $\begin{array}{c}0.056 \\
{[378058]}\end{array}$ & $\begin{array}{c}0.038 \\
{[614541]}\end{array}$ & $\begin{array}{c}0.045 \\
{[739094]}\end{array}$ & $\begin{array}{c}0.048 \\
{[760147]}\end{array}$ & $\begin{array}{c}0.041 \\
{[1337946]}\end{array}$ \\
\hline Binge Drank & $\begin{array}{c}0.118 \\
{[3928524]}\end{array}$ & $\begin{array}{c}0.192 \\
{[55426]}\end{array}$ & $\begin{array}{c}0.258 \\
{[383970]}\end{array}$ & $\begin{array}{c}0.180 \\
{[621722]}\end{array}$ & $\begin{array}{c}0.147 \\
{[746974]}\end{array}$ & $\begin{array}{c}0.102 \\
{[767567]}\end{array}$ & $\begin{array}{c}0.040 \\
{[1352865]}\end{array}$ \\
\hline $2+$ Binges & $\begin{array}{c}0.073 \\
{[3928524]}\end{array}$ & $\begin{array}{c}0.131 \\
{[55426]}\end{array}$ & $\begin{array}{c}0.163 \\
{[383970]}\end{array}$ & $\begin{array}{c}0.105 \\
{[621722]}\end{array}$ & $\begin{array}{c}0.090 \\
{[746974]}\end{array}$ & $\begin{array}{c}0.065 \\
{[767567]}\end{array}$ & $\begin{array}{c}0.026 \\
{[1352865]}\end{array}$ \\
\hline $\begin{array}{l}\text { Number of drinks } \\
\text { conditional on } \\
\text { drinking }\end{array}$ & $\begin{array}{c}20.26 \\
(35.28) \\
{[1900760]}\end{array}$ & $\begin{array}{c}26.91 \\
(51.03) \\
{[19944]}\end{array}$ & $\begin{array}{l}22.71 \\
(40.56) \\
{[222500]}\end{array}$ & $\begin{array}{c}18.32 \\
(33.05) \\
{[350855]}\end{array}$ & $\begin{array}{c}19.74 \\
(35.16) \\
{[414093]}\end{array}$ & $\begin{array}{c}20.39 \\
34.87 \\
{[386371]}\end{array}$ & $\begin{array}{c}20.61 \\
(33.80) \\
{[506997]}\end{array}$ \\
\hline
\end{tabular}


Figure 1. Pre-and Post-Legalization Trends in Traffic Fatality Rates, Ages 15-19

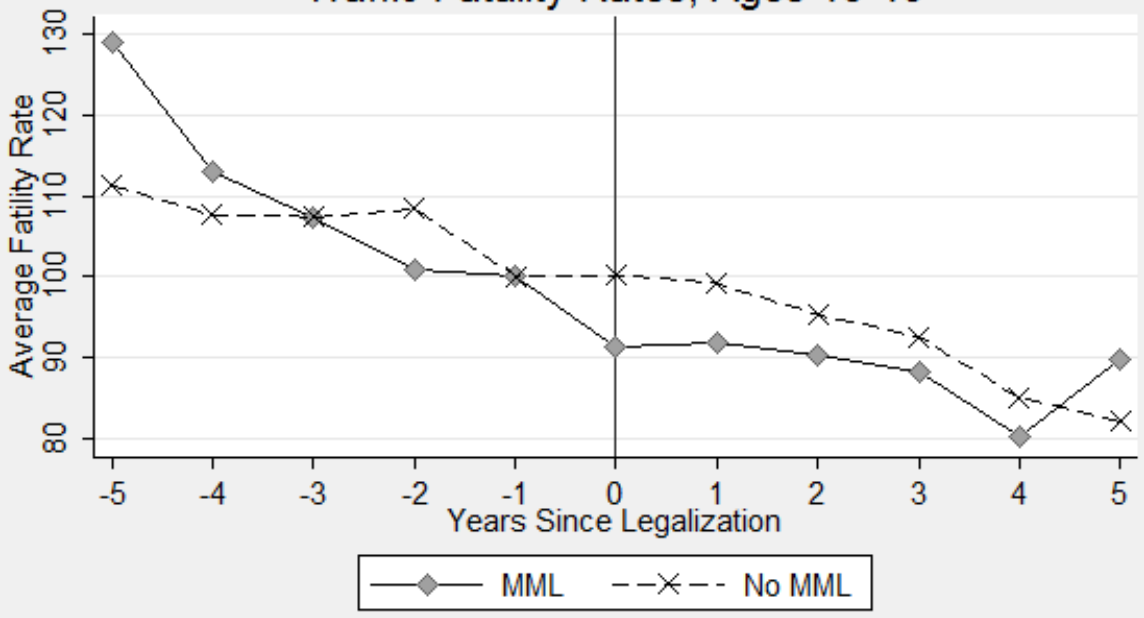

Based on FARS data for the period 1990-2010. On the horizontal axis, $O$ represents the yea in which medical marijuana was legalized. It was randomly assigned to states that did not legalize medical marijuana during the period under study. Fatality rates are expressed relative to year -1 , and are weighted by the relevant population in state $s$ and year $t$.

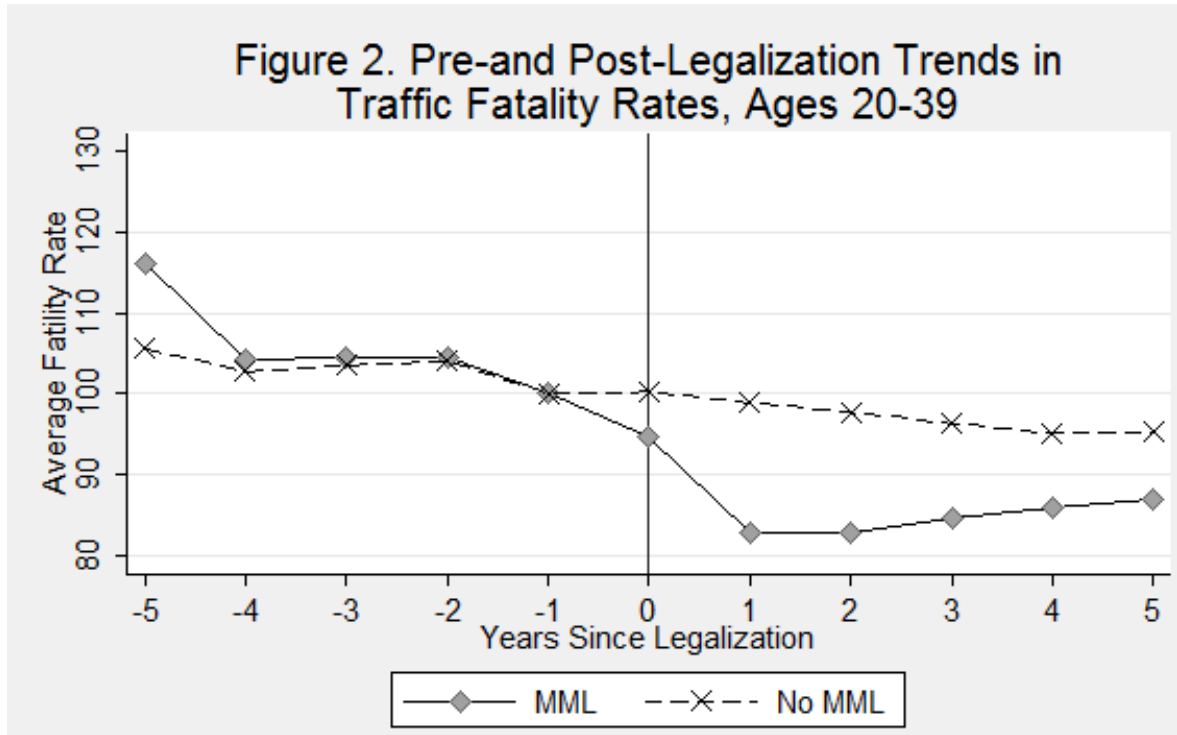

Based on FARS data for the period 1990-2010. On the horizontal axis, $O$ represents the year in which medical marijuana was legalized. It was randomly assigned to states that did not legalize medical marijuana during the period under study. Fatality rates are expressed relative to year -1 , and are weighted by the relevant population in state $s$ and year $t$. 


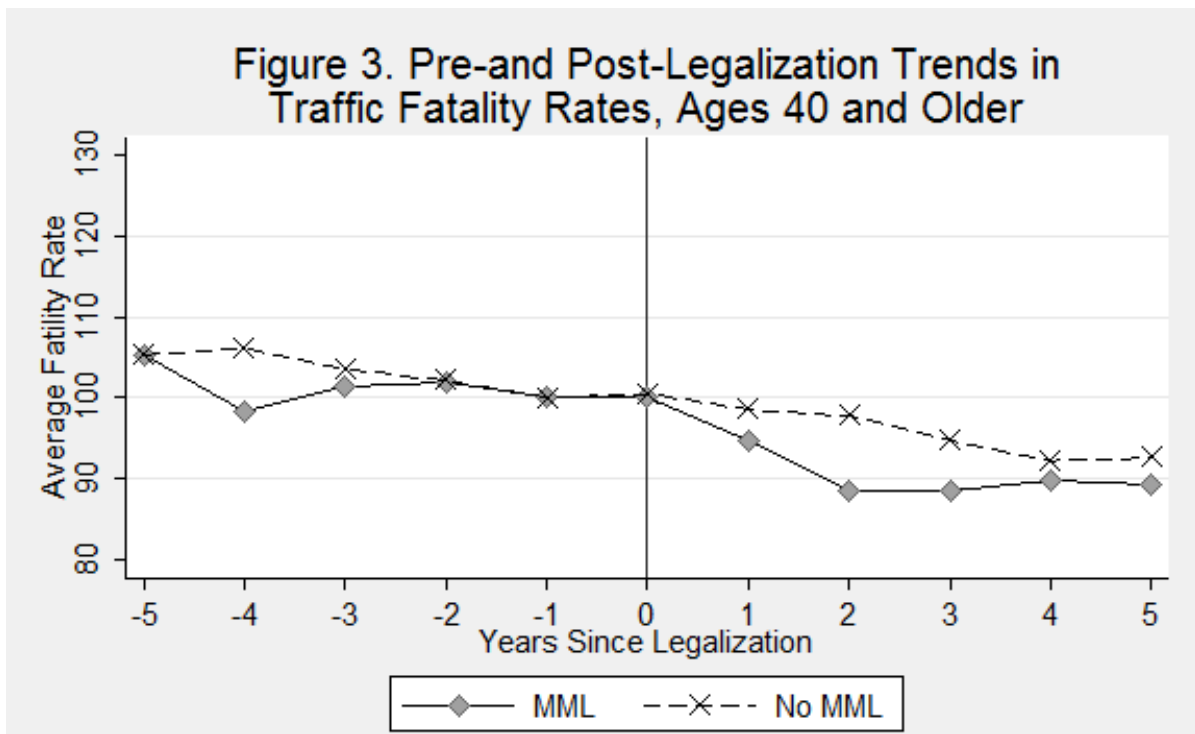

Based on FARS data for the period 1990-2010. On the horizontal axis, $O$ represents the year in which medical marijuana was legalized. It was randomly assigned to states that did not legalize medical marijuana during the period under study. Fatality rates are expressed relative to year -1 , and are weighted by the relevant population in state $s$ and year $t$. 